\title{
Interfaces in discontinuously reinforced metal matrix composites: An overview
}

\author{
R MITRA and Y R MAHAJAN \\ Defence Metallurgical Research Laboratory, Hyderabad 500258 , India
}

\begin{abstract}
The fundamental and engineering aspects pertaining to the matrix-reinforcement interfaces in discontinuously reinforced metal matrix composites are presented in this overview. The interfaces play a key role in determining mechanical properties, namely Young's modulus, yield strength, elongation, creep and fracture behaviour, as well as physical properties like coefficient of thermal expansion, thermal conductivity and damping characteristics of metal matrix composites; these are discussed in detail. The ratio of the experimental value of the Young's modulus to that predicted from the rule of mixtures has been used as a measure of interfacial bond strength. Various issues such as the nature of the interfacial bond, chemical reaction at the interfaces, and effect of alloying and processing on the structure of the interfaces and the properties of the composite are examined. In order to exploit the full potential of reinforcing the metallic matrix, the suggested strategies include creation of metallic bonding at the interface, use of in situ processing, choice of right type of alloying elements, and heat treatments and engineering of interfaces.
\end{abstract}

Keywords. Interfaces; bonding; wetting; coherency; Young's modulus; physical and mechanical properties; in situ composites; orientation relationship; interfacial energy.

\section{Introduction}

In recent years, the development of metal matrix composites (MMCs) has been receiving worldwide attention on account of their superior strength and stiffness, wear resistance, corrosion fatigue behaviour and creep resistance in comparison to the corresponding wrought alloys. The idea involved in the design of a composite material is to combine the good attributes of metals with ceramics. Metals have low stiffness values, and are ductile. Ceramics are stiff and strong, but are brittle and fail catastrophically. In MMCs, we exploit the strength of the ceramic while avoiding brittle failure. The performance of the composite depends, besides the matrix microstructure and the nature of the ceramic reinforcement, very critically on the matrix-reinforcement interface. This is schematically illustrated in figure 1. The interface plays a crucial role in the load transfer between the matrix and the reinforcement as well as in dislocation-particle interactions, which is significant in strengthening and stiffening of the composite. Moreover, physical properties such as thermal conductivity, coefficient of thermal expansion (CTE), dimensional stability, etc are also closely related to the nature of the interface. Thus it is desirable to have a clear understanding of the interfacial characteristics of specific metal matrix composites and to tailor them to achieve optimum performance in applications. In particular, the present paper addresses the issues pertaining to the interfaces in discontinuously reinforced MMCs.

\section{Matrix-reinforcement bonding}

In metal matrix composites, strengthening by the reinforcing phase is critically dependent on the strength of the bond between matrix and reinforcement. Interfacial 


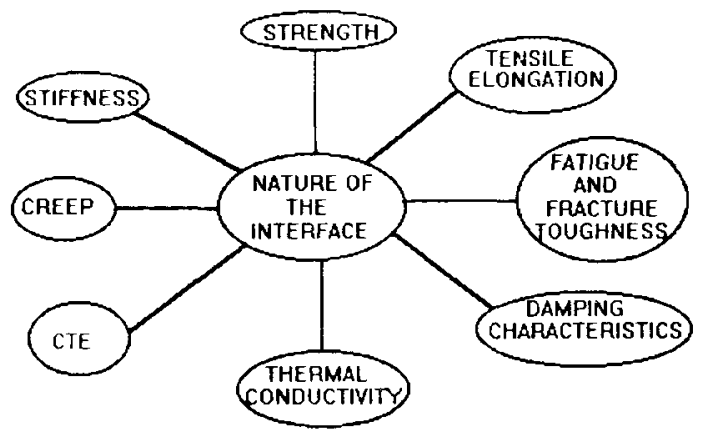

IMPORTANCE OF THE INTEAFACE

Figure 1. Schematic diagram showing relationship of interface characteristics to different physical and mechanical properties.

bonding can be categorized as mechanical and chemical (Chawla 1987). Mechanical bonding is significant only in the case of fibre-reinforced composites, when fibres have rough or faceted surfaces. Chemical bonding is important for all kinds of reinforcements: fibres, whiskers and particulates. A chemical bond is possible only if the atoms of the matrix and reinforcement are in direct contact and is accomplished by an exchange of electrons, and the type of exchange determines the character of the bond. It can be metallic, which is non-directional, or ionic or covalent, which are directional. An interface with a metallic bond is thus more ductile than that with ionic or covalent bonds. For example, $\mathrm{Fe}-\mathrm{Fe}_{3} \mathrm{C}$ interfaces in steel do not show fatigue crack initiation (Sunwoo et al 1982) as found in $\mathrm{Fe}-\mathrm{Al}_{2} \mathrm{O}_{3}$ interfaces (Eid and Thomason 1979). Interface segregants and chemical reaction can also affect the strength of the individual atomic bonds at the interface, which ultimately reflects on the macroscopic strength.

\section{Reactive interfaces}

A chemical reaction at the interface may lead to a strong bond between the matrix and the reinforcement, but a brittle reaction product can be highly detrimental to the performance of the composite. Table 1 gives matrices and reinforcements with reaction products seen at the interfaces. A ceramic-ceramic bond (reaction productceramic reinforcement) is weaker and more brittle than metal-ceramic or metalintermetallic bond. Hence cracks initiate by cracking of the reaction product or the reaction product-matrix interface. For example, $\mathrm{Al}_{4} \mathrm{C}_{3}$ which forms as a reaction product at $\mathrm{Al}$ matrix-SiC fibre interface during processing by melting and casting acts as site for crack initiation (Clough et al 1990). Figure 2 shows an $\mathrm{Al} / \mathrm{TiC}$ interface with reaction products comprising $\mathrm{Al}_{3} \mathrm{Ti}$ and $\mathrm{Al}_{4} \mathrm{C}_{3}$; sharp cracks can be observed. These occurred during cold rolling (Mitra et al 1993a). Thus, it is essential that the matrix and reinforcement coexist in thermodynamic equilibrium under processing or service conditions. This is the first criterion in choice of ceramic reinforcements for any metal matrix. Alloying can be used to prevent progress of chemical reactions. Addition of 
Table 1. Reaction products at some of the matrix/reinforcement interfaces.

\begin{tabular}{|c|c|c|c|}
\hline Matrix & Reinforcement & $\begin{array}{l}\text { Reaction products } \\
\text { and precipitates }\end{array}$ & References \\
\hline \multicolumn{4}{|l|}{ Aluminium } \\
\hline $\mathrm{Al}$ & $\mathrm{SiC}$ & $\mathrm{Al}_{4} \mathrm{C}_{3}, \mathrm{Al}(\mathrm{Si})$ & Iseki et al (1984); Lee et al (1988) \\
\hline $\mathrm{Al}-\mathrm{Mg}$ & $\mathrm{SiC}$ & $\mathrm{Mg}_{2} \mathrm{Si}, \mathrm{Al}_{4} \mathrm{C}_{3}, \mathrm{MgO}$ & Rack (1988) \\
\hline $\begin{array}{l}\mathrm{Al}-\mathrm{Cu}-\mathrm{Mg} \\
1985\end{array}$ & $\mathrm{SiC}$ & $\mathrm{CuMgAl}, \mathrm{MgO}$ & $\begin{array}{l}\text { Nutt (1986); Nutt and Carpen- } \\
\text { ter (1985) }\end{array}$ \\
\hline $\mathrm{Al}$ & $\mathrm{B}_{4} \mathrm{C}$ & $\mathrm{AlB}_{2}, \mathrm{Al}_{4} \mathrm{C}_{3}$ & Lucas et al (1992) \\
\hline $\mathrm{Al}-\mathrm{Mg}$ & $\mathrm{B}_{4} \mathrm{C}$ & $\begin{array}{l}\mathrm{AlB}_{2}, \mathrm{MgB}_{2} \\
\mathrm{Al}_{x} \mathrm{Mg}_{(1-x)} \mathrm{B}_{2}, \mathrm{Al}_{4} \mathrm{C}_{3} \\
\mathrm{Al}_{x}(\mathrm{~B}-\mathrm{C}-\mathrm{O})_{1-x}, \mathrm{MgB}_{6}\end{array}$ & Lucas et al (1992) \\
\hline $\mathrm{Al}$ & $\mathrm{TiC}$ & $\mathrm{Al}_{4} \mathrm{C}_{3}, \mathrm{Al}_{3} \mathrm{Ti}$ & $\begin{array}{l}\text { Yokokawa et al (1991); } \\
\text { Satyaprasad et al (1992); Mitra } \\
\text { et al (1993a) }\end{array}$ \\
\hline $\mathrm{Al}$ & $\mathrm{TiB}_{2}$ & No reaction & Mitra et al (1993); Mitra (1993) \\
\hline $\mathrm{Al}-\mathrm{Mg}$ & $\mathrm{Al}_{2} \mathrm{O}_{3}$ & $\mathrm{MgAl}_{2} \mathrm{O}_{4}$ & Levi et al (1978) \\
\hline $\mathrm{Al}-\mathrm{Cu}$ & $\mathrm{Al}_{2} \mathrm{O}_{3}$ & $\mathrm{CuAl}_{2} \mathrm{O}_{4}$ & Sritharan et al (1990) \\
\hline $\mathrm{Al}-\mathrm{Li}$ & $\mathrm{Al}_{2} \mathrm{O}_{3}$ & $\begin{array}{l}\alpha-\mathrm{LiAlO}_{2}, \mathrm{LiAl}_{5} \mathrm{O}_{8} \\
\mathrm{Li}_{2} \mathrm{O}\end{array}$ & $\begin{array}{l}\text { Chawla (1987); Sritharan et al } \\
(1990)\end{array}$ \\
\hline \multicolumn{4}{|l|}{ Titanium } \\
\hline $\mathrm{Ti}$ & $\mathrm{SiC}$ & $\mathrm{TiC}, \mathrm{Ti}_{5} \mathrm{Si}_{3}, \mathrm{Ti}_{x} \mathrm{Si}_{y}$ & $\begin{array}{l}\text { Jones et al (1989); Reeves et al } \\
\text { (1991) }\end{array}$ \\
\hline $\mathrm{Ti}$ & $\mathrm{TiC}$ & $\mathrm{Ti}_{2} \mathrm{C}$ & Konitzer and Loretto (1989a) \\
\hline $\mathrm{Ti}-\mathrm{Al}-\mathrm{V}-\mathrm{Nb}$ & $\mathrm{TiC}$ & $\mathrm{Ti}_{2}(\mathrm{Al}, \mathrm{Nb}) \mathrm{C}$ & Konitzer and Loretto (1989b) \\
\hline $\mathrm{Ti}$ & $\mathrm{TiB}_{2}$ & TiB & Reeves et al (1991) \\
\hline \multicolumn{4}{|l|}{ Magnesium } \\
\hline $\mathrm{Mg}$ & $\mathrm{SiC}$ & $\mathrm{Mg}_{2} \mathrm{Si}, \mathrm{C}$ & Brown (1993) \\
\hline $\mathrm{Mg}-\mathrm{Li}$ & $\mathrm{SiC}$ & $\mathrm{Mg}_{2} \mathrm{Si}, \mathrm{Li}_{2} \mathrm{C}_{2}$ & Warwick and Clyne (1989) \\
\hline $\mathrm{Mg}-\mathrm{Li}$ & $\begin{array}{l}\mathrm{SiC} \text { with } \\
\mathrm{SiO}_{2} \text { coating }\end{array}$ & $\mathrm{Mg}_{2} \mathrm{Si}, \mathrm{Li}_{2} \mathrm{O}$ & Warwick and Clyne (1989) \\
\hline $\mathrm{Mg}$ & $\mathrm{Al}_{2} \mathrm{O}_{3}$ & $\mathrm{MgAl}_{2} \mathrm{O}_{4}$ & Chawla (1987) \\
\hline \multicolumn{4}{|l|}{ Intermetallics } \\
\hline $\mathrm{NiAl}$ & $\mathrm{SiC}$ & $\mathrm{Ni}_{x} \mathrm{Si}_{y}, \mathrm{Al}_{4} \mathrm{C}_{3}$ & Chawla (1987) \\
\hline $\mathrm{NiAl}$ & $\mathrm{TiB}_{2}$ & No reaction & Wang and Arsenault (1991) \\
\hline $\mathrm{NiAl}$ & $\mathrm{TiC}$ & No reaction & Fuchs $(1990)$ \\
\hline $\mathrm{Ni}-\mathrm{Al}-\mathrm{Cr}-\mathrm{Zr}-\mathrm{B}$ & $\mathrm{TiB}_{2}$ & $(\mathrm{Ti}, \mathrm{Zr}) \mathrm{B}_{2}$ & Fuchs $(1990)$ \\
\hline $\mathrm{Al}_{3} \mathrm{Ti}$ & $\mathrm{TiC}$ & No reaction & Norman (1990) \\
\hline $\mathrm{TiAl} / \mathrm{Ti}_{3} \mathrm{Al}$ & $\mathrm{TiB}_{2}$ & No reaction & Feng et al (1991) \\
\hline $\mathrm{MoSi}_{2}$ & $\mathrm{SiC}$ & No reaction & Meschter and Schwartz (1989) \\
\hline $\mathrm{MoSi}_{2}$ & $\mathrm{TiC}$ & No reaction & Meschter and Schwartz (1989) \\
\hline $\mathrm{MoSi}_{2}$ & $\mathrm{Al}_{2} \mathrm{O}_{3}$ & $\operatorname{SiO}(g), A l i g)$ & Meschter and Schwartz (1989) \\
\hline $\mathrm{Ti}_{5} \mathrm{Si}_{3}$ & $\mathrm{SiC}$ & TiSi, TiC & Meschter and Schwartz (1989) \\
\hline
\end{tabular}

$3 \% \mathrm{Si}$, which raises significantly the activity of $\mathrm{Si}$ in $\mathrm{Al}$, completely stops the reaction (Sritharan et al 1990)

$$
(4+x) \mathrm{Al}(\mathrm{l})+3 \mathrm{SiC}(\mathrm{s}) \rightarrow \mathrm{Al}_{4} \mathrm{C}_{3}(\mathrm{~s})+3 \mathrm{Si}(x \mathrm{Al}),
$$

from progressing in the forward direction according to the law of mass action. 


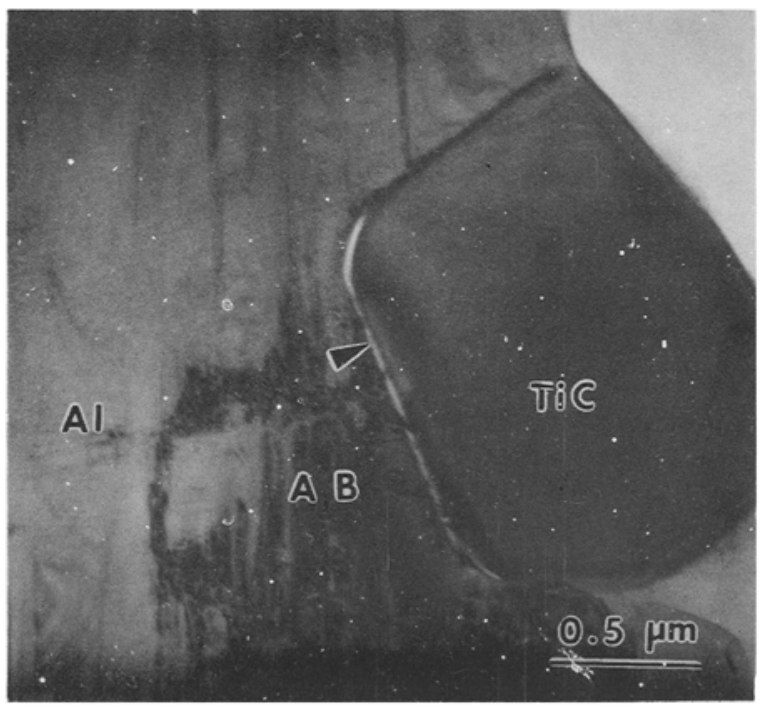

Figure 2. TEM micrograph showing interfacial crackıng due to cold rolling of XD Al TiC composite heat-treated for $24 \mathrm{~h}$ at $640 \mathrm{C}$. Heat treatment leads to formation of reaction product $\mathrm{Al}_{3} \mathrm{Ti}_{1}(\mathrm{~A})$ and $\mathrm{Al}_{4} \mathrm{C}_{3}(\mathrm{~B})$ at interfaces (Mitra et al $1993 \mathrm{a}$ ).

\section{Type of reinforcement and electronic bonding}

Even if the reinforcement is chemically compatible with the matrix. the strength and nature of the electronic interaction between matrix and reinforcement and structure and chemistry of interface are important for efficient load transfer. Thus it has been observed that for similar process variables, and in the absence of any chemical reaction product at the interface, the increase in Young's modulus by incorporation of the reinforcement in a metallic matrix provides a measure of the interfacial bond integrity between the matrix and the reinforcement. Two ways of averaging have been proposed: (i) Voight (1928) assumes uniform strain in both the constituent phases and (ii) Reuss (1929) assumes uniform stress in both the phases. The Voight averaging, also known as "rule of mixtures" (ROM) leads to

$$
E_{\mathrm{v}}=V_{\mathrm{m}} E_{\mathrm{ri \textrm {s }}}+V_{\mathrm{p}} E_{\mathrm{p}}
$$

where $E_{\mathrm{c}}, E_{\mathrm{m}}$ and $E_{\mathrm{p}}$ are Young's modulus values of the composite, matrix and reinforcement particles respectively and $V_{\mathrm{m}}$ and $V_{\mathrm{p}}$ are volume fractions of matrix and reinforcement phases.

The Ruess averaging gives

$$
E_{\mathrm{r}}=1 /\left(V_{\mathrm{m}} ; E_{\mathrm{m}}\right)+\left(V_{\mathrm{p}}\left(E_{\mathrm{p}}\right)\right\} \text {. }
$$

Figure 3 consists of bar diagrams for pure $\mathrm{Al}$ matrix $\mathrm{P} / \mathrm{M}$ composites with $20 \mathrm{vol} \%$ $\mathrm{SiC}, \mathrm{TiC}, \mathrm{TiB}_{2}$ and $\mathrm{B}_{4} \mathrm{C}$ particulate reinforcements showing the ratios of experimental Young's modulus (Kuruvilia et al 1989: Mahajan and Rama Rao 1992) values to those predicted by the rule of mixtures. TEM study did not reveal the presence of any reaction products at the mairix/reinforcement interface in these composites in the hot 


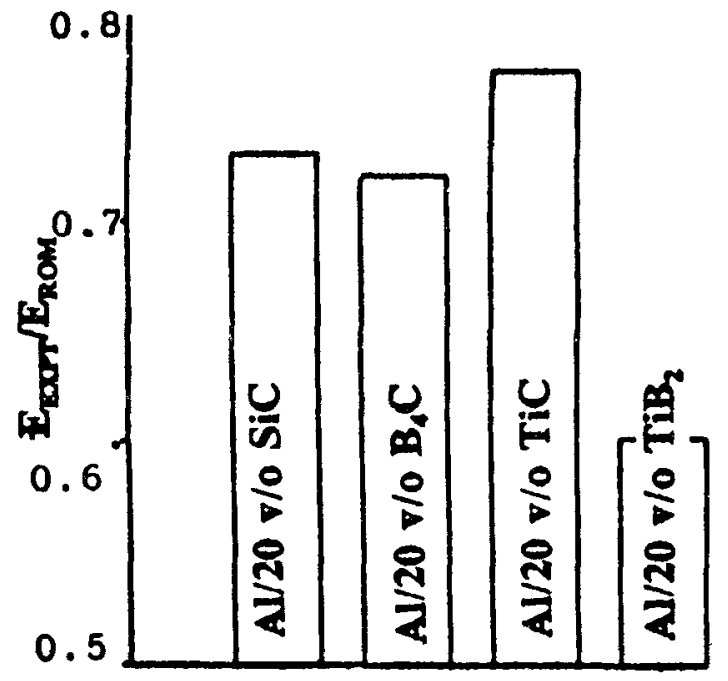

Figure 3. $E(\operatorname{expt}) / E(\mathrm{ROM})$ for Al matrix composites with different reinforcements (Kuruvilla et al 1989). Al/ TiC shows the highest ratio.

rolled condition (Kuruvilla et al 1989). The process details have been published elsewhere (Kuruvilla et al 1989; Jain et al 1993). It is clear from figure 3 that Al/TiC shows the best correlation between theoretical and experimental values and $\mathrm{Al} / \mathrm{TiB}_{2}$ composite shows the worst, suggesting that the former has the strongest interfacial bond and the latter has the weakest among the four systems studied. In another investigation with $\mathrm{P} / \mathrm{M} \mathrm{Al}-\mathrm{Ti}$ alloy containing $\mathrm{Al}_{3} \mathrm{Ti}, \mathrm{Al}_{4} \mathrm{C}_{3}$ and $\mathrm{Al}_{2} \mathrm{O}_{3}$ as dispersoids (Hawk et al 1988), only changes in the volume fraction of the intermetallic compound $\mathrm{Al}_{3}$ Ti could be correlated with change in Young's modulus, whereas those of $\mathrm{Al}_{4} \mathrm{C}_{3}$ and $\mathrm{Al}_{2} \mathrm{O}_{3}$ had a negligible effect. It is also interesting to note that rule of mixtures (Voigt law of averaging) was closely followed. Observations of Zedalias et al (1985) with $\mathrm{Al}_{3} \mathrm{Zr}$ dispersoids and Skinner (1988) with $\mathrm{Al}_{13}(\mathrm{FeV})_{3} \mathrm{Si}$ dispersoids in pure $\mathrm{Al}$ also show excellent correlation between experimental values of Young's modulus and those predicted by rule of mixtures in the case of intermetallic dispersoids. Fine (1981) has shown that changes in Young's modulus values with volume fraction of $\mathrm{MnAl}_{6}$ and $\mathrm{Al}_{2} \mathrm{O}_{3}$ dispersoids in pure $\mathrm{Al}$ follow the Voigt and Ruess laws of averaging, respectively. A well-bonded interface would allow the maximum transfer of load from the matrix to the reinforcement and is expected to exhibit a high value of $E(\operatorname{expt}) / E(\mathrm{ROM})$ ratio, whereas a weakly bonded interface will result in lower $E(\operatorname{expt}) / E(\mathrm{ROM})$ ratio. In the case of the latter, values predicted by Ruess law of averaging will be closer to experimental values. Figure 4 shows bar diagrams of $E(\mathrm{expt}) / E(\mathrm{ROM})$ for four systems, namely $\mathrm{Al} / \mathrm{Al}_{3} \mathrm{Zr}$ (Zedalias et al 1985), $\mathrm{Cu} / \mathrm{Fe}$ (Krock 1966), $\mathrm{Al} / \mathrm{SiC}$ (Bonollo et al 1991) and $\mathrm{Al} / \mathrm{Al}_{2} \mathrm{O}_{3}$ (Lyle 1967). It is seen that metal-intermetallic and metal-metal systems show $E(\operatorname{expt}) / E(\mathrm{ROM})$ values close to 1 . Also, $E($ expt $) / E(\mathrm{ROM})$ for $\mathrm{Al} / \mathrm{TiC}$ was higher than those of $\mathrm{Al} / \mathrm{SiC}, \mathrm{Al} / \mathrm{TiB}_{2}$ and $\mathrm{Al} / \mathrm{B}_{4} \mathrm{C}$ (figure 3 ). In case of $\mathrm{TiC}$ and intermetallic compounds as dispersoids, it is obvious that the matrix-reinforcement bond is stronger. Of course, the bonds between $\mathrm{Al}$ and the intermetallic compounds are metallic. At a metal-ceramic interface, there is a sharp discontinuity in the electronic structure due to delocalized nature of 


\section{CHEMICAL NATURE OF DISPERSOID}

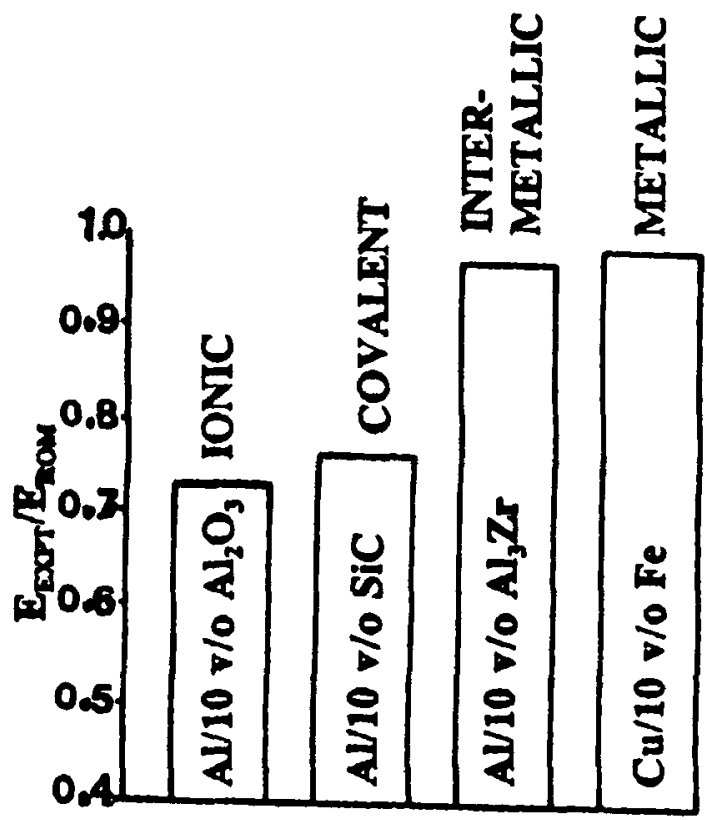

Figure 4. $E$ (expt) $/ E$ (ROiM) for $\mathrm{Cu} / \mathrm{Fe}$ (Krock 1966), $\mathrm{Al} / \mathrm{Al}_{3} \mathrm{Zr}$ (Zedalia et al 1985), $\mathrm{Al} / \mathrm{SiC}$ (Bonollo et al 1991) and $\mathrm{Al} / \mathrm{Al}_{2} \mathrm{O}_{3}$ (Lyle 1967) systems.

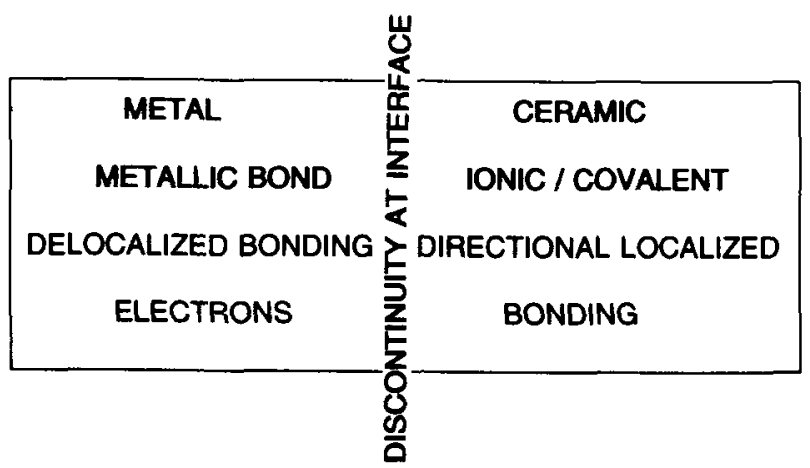

Figure 5. Schematic representation of discontinuity in the electronic structure at a metalceramic interface.

electrons in the metal and highly localized electrons in the covalently or ionically bonded ceramic reinforcement. Figure 5 shows a schematic diagram. This affects the wetting behaviour, and degree of interaction at the interface increases with lowering of this discontinuity. This agrees well with observations of Nicholas (1987), in which the degree of wetting of carbides and oxides by $\mathrm{Cu}$ decreased with increase in ionicity. Thus a weakly ionic or covalent ceramic will have a stronger bond with a metal compared to those which are strongly ionic or covalent. In metal-ceramic bonding, transition metal carbides like $\mathrm{TiC}$ which have partial metallic nature (Rhee 1970) thus 
show stronger bond with $\mathrm{Al}$, a reactive metal, than more covalent bonded ceramics (Delannay et al 1987) like $\mathrm{TiB}_{2}$ (table 2). Rhee (1970) observed that wetting increased in the order $\mathrm{AlN}<\mathrm{TiB}_{2}<\mathrm{TiN}<\mathrm{TiC}$, and suggested the metallic character of $\mathrm{TiC}$ to be the reason for excellent wetting characteristics. Goretzki et al (1971) suggested a higher degree of overlapping of the electronic state wave functions in cases where both the components are metallic. For metal-like transition carbides, the density of states and work of adhesion vary with valence electron concentration in the same manner.

Comparing $\mathrm{TiC}$ and $\mathrm{TiB}_{2}$, it is also clear that the latter has a higher heat of formation and is more stable. It has also been reported by Ramqvist (1965) that carbides with lower heat of formation are wetted better by metals than those with higher heat of formation. Also, from table 1 , it is clear that $\mathrm{TiC}$ reacts with $\mathrm{Al}$ under certain conditions, whereas $\mathrm{TiB}_{2}$ does not. Thus higher stability of $\mathrm{TiB}_{2}$ in $\mathrm{Al}$ compared to that of $\mathrm{TiC}$ is another reason why the latter is wetted better.

$\mathrm{Ni}-16 \mathrm{Al}-8 \mathrm{Cr}-1 \mathrm{Zr}-0.1 \mathrm{~B}$ matrix with $\mathrm{TiC}, \mathrm{Al}_{2} \mathrm{O}_{3}$ and $\mathrm{TiB}_{2}$ reinforcement prepared by $\mathbf{P} / \mathbf{M}$ route has also been investigated (Fuchs 1990 ). While $\mathrm{TiB}_{2}$ was not chemically compatible with the matrix, both $\mathrm{TiC}$ and $\mathrm{Al}_{2} \mathrm{O}_{3}$ were stable in the matrix. Interestingly, reinforcing with $\mathrm{TiC}$ has shown excellent bond integrity leading to much higher modulus and yield strength compared to those with $\mathrm{Al}_{2} \mathrm{O}_{3}$. This again can be explained by the metallic nature of $\mathrm{TiC}$ and strong interaction of $\mathrm{Ti}$ with both $\mathrm{Ni}$ and $\mathrm{Al}$.

The above observations can be better appreciated with an understanding of wetting mechanisms. Wetting defines the extent of interaction between a liquid and a solid during fabrication of a composite and determines the bond strength. The mechanisms include, other than chemical reaction, Van der Waals and image forces, adsorption and electronic bonding ( $\mathrm{Oh}$ et al 1989). It makes sense to believe that the adhesive force between a reactive metal and a reinforcement is dependent on the electronic properties of the latter, as the former will always have free electrons in the conduction band. Thus a ceramic reinforcement with more metallic nature is wetted better than those which are more covalent or ionic. Thus $\mathrm{TiC}$ and $\mathrm{Al}_{3} \mathrm{Ti}$ act as effective nucleants during solidification of $\mathrm{Al}$ as has been reported by Cisse et al (1972). The fact that $\mathrm{Al}$ solidified with an epitaxial orientation relationship with respect to $\mathrm{Al}$, that is, $(001) \mathrm{Al} / /(001) \mathrm{TiC}$ and $[001] \mathrm{Al} / /[001] \mathrm{TiC}$, of course suggests that under equilibrium conditions interfaces of low energy form between $\mathrm{Al}$ and $\mathrm{TiC}$. A similar phenomenon was observed for $\mathrm{Al}_{3} \mathrm{Ti}$ too, and it has been seen from the data reported earlier that bond integrity between $\mathrm{Al}$ and these reinforcements are excellent. Thus good wetting

Table 2. A comparison of bonding, reactivity with $\mathrm{Al}$ and wetting characteristics of $\mathrm{TiC}$ and $\mathrm{TiB}_{2}$.

\begin{tabular}{lcccc}
\hline Compound & $\begin{array}{c}H_{\mathrm{f}} \\
(\mathrm{kJ} / \mathrm{mol})\end{array}$ & $\begin{array}{c}\text { \% Covalent } \\
\text { bond }\end{array}$ & $\begin{array}{l}\text { Reactivity with } \\
\text { reaction } \mathrm{G}_{\mathrm{f}} \\
\text { product }(\mathrm{kJ})\end{array}$ & $\begin{array}{c}\text { Contact angle } \\
\text { with } \mathrm{Al}(\mathrm{l}) \text { at } \\
1080 \mathrm{~K} \\
(\cos \theta)\end{array}$ \\
\hline $\mathrm{TiC}$ & 10.5 & 80 & $\begin{array}{l}\mathrm{Al}_{3} \mathrm{Ti},-5 \\
\mathrm{Al}_{4} \mathrm{C}_{3} \\
\mathrm{Al}_{3} \mathrm{Ti}_{4}, 44.6 \\
\mathrm{AlB}_{2}\end{array}$ & 0.7 \\
\hline
\end{tabular}


of $\mathrm{TiC}$ by $\mathrm{Al}$ occurs as has been reported in the literature (Samsonov et al 1968; Manning and Gurganus 1969; Rhee 1970).

Chemistry and crystallography of surfaces, which play a significant role in determining electronic density of states of surface atoms, also affect the wetting behaviour. For example, photoemission spectra from $\mathrm{TiC}\{\mathbf{1 1}\}$ surfaces have shown high density of states near the Fermi level similar to Ti $\{0001\}$ surfaces (Bradshaw et al 1980) and $r_{i}$ ence their behaviour with respect to wetting by $\mathrm{Al}$ is similar. An interesting observation in XD Al/TiC composite was that the interface plane of TiC was mostly $\{111\}$ (figure 6) (Mitra et al 1993b). Besides its metallic nature which improves bonding, these planes are densely packed and result in maximization of number of bonds with matrix and lowering the interfacial energy. Similar observations were also made by Gao and Merkle (1992) for equilibrium and nonequilibrium metal-metal oxide interfaces.

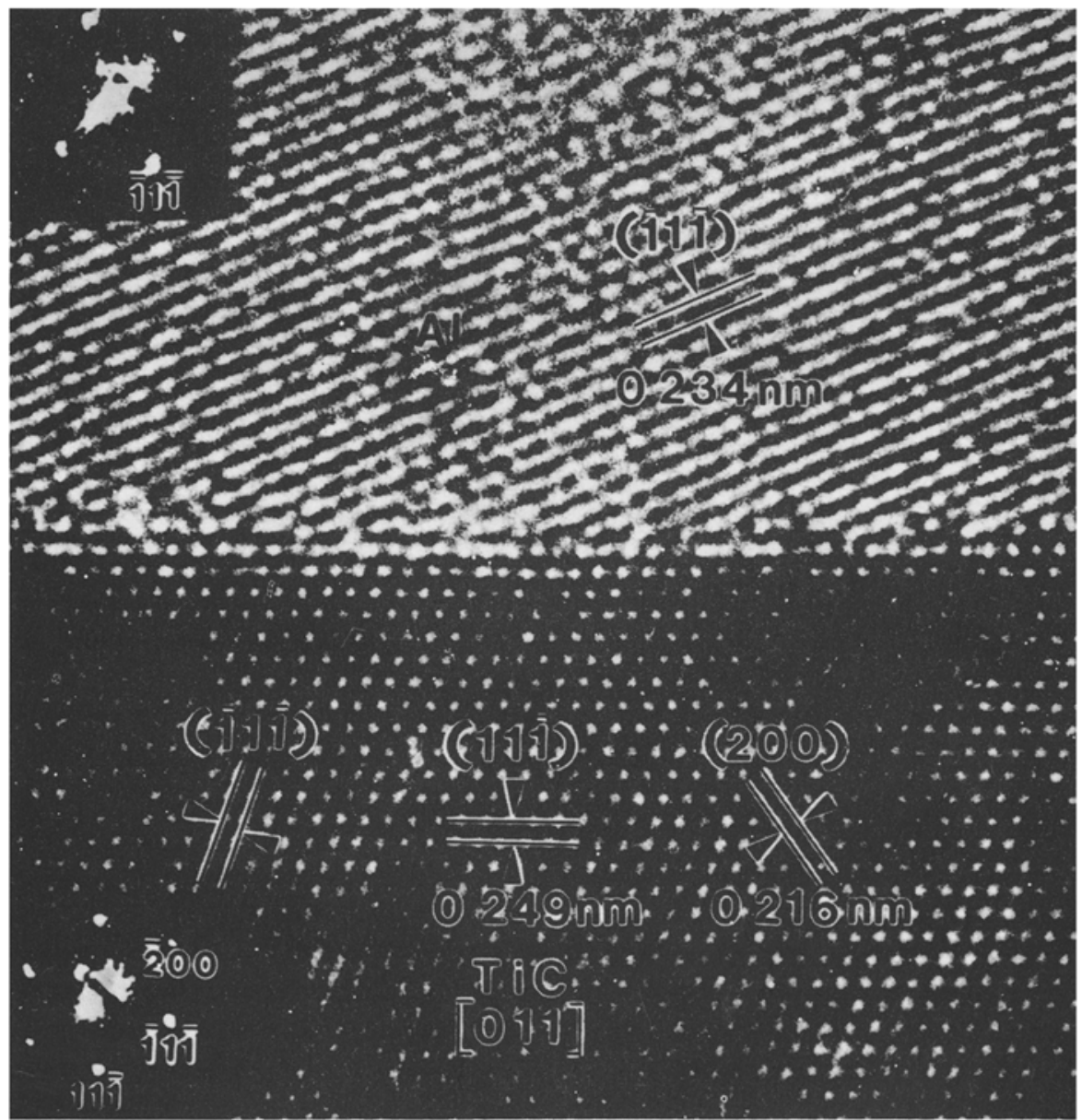

Figure 6. High-resolution TEM micrograph showing the particle/matrix interface in $\mathrm{Al} / \mathrm{TiC}$ composite prepared by XD process. The interface is abrupt on an atornic scale and is parallel to TiC(111) plane, which is densely packed (Mitra et al 1993b). 
In another experiment, Ohuchi (1987) observed that $\mathrm{Cu}$ adhered more strongly to AlN $\{0001\}$ surfaces compared to AIN $\{1012)$ or AIN $\{1011\}$ surfaces. The reason for this was the fact that $\mathrm{Cu}$ bonds to $\mathrm{Al}$ atoms during interaction and hence $\mathrm{AlN}\{0001\}$ surfaces containing only $\mathrm{Al}$ atoms were more favourable.

The differences in dielectric constants of the metal and the ceramic reinforcements (mainly oxide and carbide) also play a leading role in chemical bonding as this gives rise to image forces at the interface (Stoneham and Tasker 1985; Finnis et al 1990). The effect is strengthened if there are charged defects on the surfaces of the ceramic as these will have lower energy of formation at the interface than at a free surface. Thus an oxide or carbide which tends to lose stoichiometry more easily or have lower binding energy will be wetted better compared to one that is more stable. In a study of wetting characteristics of $\mathrm{MgO}$ single crystal by $\mathrm{Pb}, \mathrm{Sn}$ and $\mathrm{Bi}$ liquid metals by Nogi et al (1992), it was observed that degree of polarization, type of charge distribution and atomic arrangements on the surface controlled the degree of wetting by the liquid metal.

$\mathrm{TiC}$ also is an excellent example. Atom fraction of carbon in TiC varies from $33 \%$ to $48 \%$ without any change in its crystal structure (Goretzki 1967). Nicholas (1987) has reported the wetting behaviour of $\mathrm{TiC}$ by $\mathrm{Cu}$ for different atom fractions of $\mathrm{C}$ in $\mathrm{TiC}$, and the contact angle decreased with decrease in atom fraction of $\mathrm{C}$, proving the better wettability of nonstoichiometric carbides. Stacking faults and dislocations have been seen close to $\mathrm{Al}-\mathrm{TiC}$ interface using high-resolution transmission electron microscopy (HRTEM), and figure 7 shows an example. The fact that charged defects at the surface of ceramic reinforcement improves wetting suggests that irradiation of ceramic substrates or fibres will lead to better bonding with metal and this has been observed by Tombrello (1984). Fuchs et al (1989) observed significant improvement in $\mathrm{Cu}-\mathrm{Al}_{2} \mathrm{O}_{3}$ bonding due to ion-beam mixing of interface. After irradiation with $1.5 \mathrm{MeV} \mathrm{Xe}{ }^{+}$ions of an $\mathrm{Al}_{2} \mathrm{O}_{3}$ substrate, the surface roughness increased and the 6-nm-thick interface region was modified.

\section{Work of adhesion and bonding: Effect of alloying elements and coherency}

Work of adhesion $W_{\text {ad }}$ of a particle-matrix interface is strongly affected by alloying element additions. Work of adhesion is defined as the energy of creation of free surfaces of particle and matrix by rupturing of the interfacial bond. Work of adhesion for solid/solid interface is given by

$$
W_{\mathrm{ad}}=\tau_{\mathrm{mv}}+\tau_{\mathrm{pv}}-\tau_{\mathrm{mp}},
$$

where $\tau_{\mathrm{mv}}$ and $\tau_{\mathrm{pv}}$ are the surface energies of matrix and particle and $\tau_{\mathrm{mp}}$ is the particle-matrix interfacial energy. Figure 8 is a schematic diagram of a void formed at a particle-matrix interface. The void is created during deformation, and annealing treatment is conducted to reach equilibrium. If $\theta$ is the contact angle between a particle facet and a spherical cap-shaped void, the force equilibrium in the horizontal direction gives

$$
\tau_{\mathrm{mp}}=\tau_{\mathrm{mv}} \cos \theta+\tau_{\mathrm{pv}} .
$$

This is Young's equation (1805). Substituting (4) in (3), we get

$$
W_{\mathrm{ad}}=\tau_{\mathrm{mv}}(1-\cos \theta) .
$$




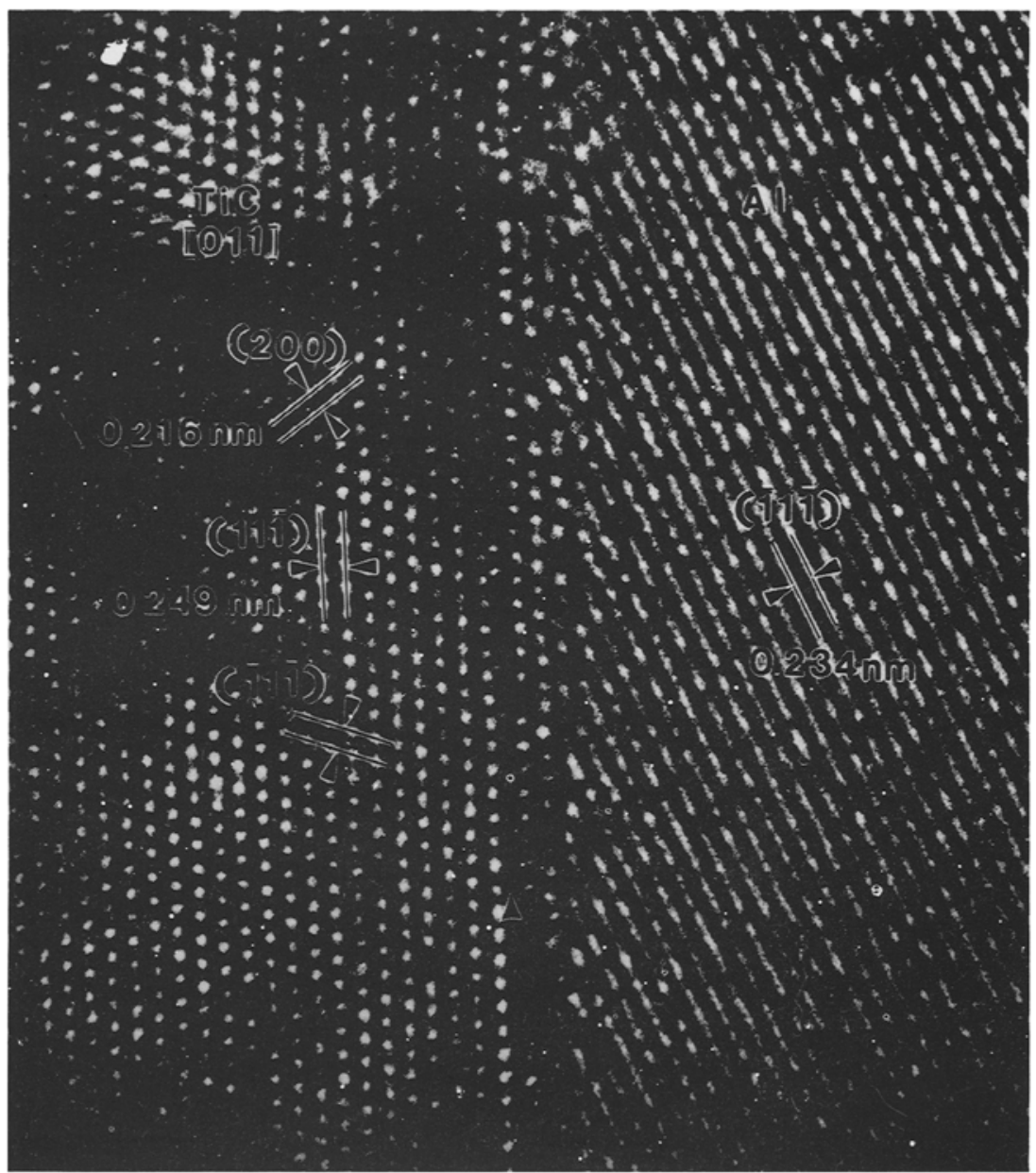

Figure 7. High-resolution TEM micrograph showing the particle/matrix interface in $\mathrm{Al} / \mathrm{TiC}$ composite prepared by $\mathrm{XD}$ process. The first three atomic layers inside $\mathrm{TiC}$ near the interface appear distorted due to a stacking fault (arrowed) on the ( $11 \overline{1}$ ) TiC planes (shown with an arrow-head). Position of an extra half plane of an edge dislocation is shown with an arrow (Mitra et al 1993b).

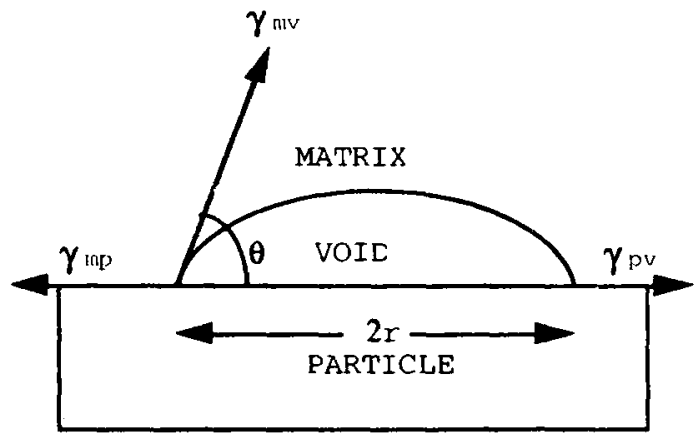

Figure 8. A spherical cap-shaped void formed at the interface a TiC particle facet and matrix (Mitra 1993). 
Contact angle and interfacial energies were measured for $\mathrm{XD} \mathrm{Al} / \mathrm{TiC}$ composite from voids created by deformation followed by annealing at $500^{\circ} \mathrm{C}$ for $2 \mathrm{~h}$. There was a variation in the interfacial energy from 200 to $850 \mathrm{~mJ} \mathrm{~m}^{-2}$. It is believed that for partially coherent interfaces, interfacial energy varies based on the orientation relationships and degree of coherency. Particles occurring at grain boundaries are expected to have much higher interfacial energies.

Easterling et al (1973) used (5) for determining the $W_{\text {ad }}$ between the particle and the matrix in the $\mathrm{Fe}-\mathrm{Ni} / \mathrm{Al}_{2} \mathrm{O}_{3}$ composite. Contact angle was seen to change very sharply with changes in atomic fraction of alloying elements in the matrix and so did the work of adhesion as shown in table 3. It was also observed that the flow stress was directly related to the work of adhesion.

Segregation of alloying elements to the interface reduces interfacial energy due to the Gibbs adsorption phenomenon. However, this may be detrimental to interface toughness if the alloying elements lead to an increase in the ionic or covalent character of the interface bonding (Fine et al 1988). Alloying elements play a significant role in coarsening behaviour of precipitates in metal-intermetallic composites (Calderon et al 1988). For example, in $\mathrm{Fe}-\mathrm{Ni}-\mathrm{Al}$ alloys containing a few per cent of $\mathrm{Mo}$, the $\mathrm{NiAl}$ particles remain spherical upon ageing even though the particle-matrix lattice misfit is considerable. This is in contrast to that in absence of Mo, when the precipitates turn cuboidal. It has been suggested that Mo segregation at the interface relaxes the elastic misfit strains or changes the interfacial energy such that even large precipitates remain spherical.

Nature of the chemical bond also depends on alloying elements. For example, addition of $\mathrm{Mg}$ to $\mathrm{Al}-\mathrm{Al}_{2} \mathrm{O}_{3}$ composites leads to the formation of $\mathrm{MgO}$ and $\mathrm{MgAl}_{2} \mathrm{O}_{4}$ at the interface (Levi et al 1978; Chawla 1987; Sritharan et al 1990) and this enhances the wettability which is otherwise poor. The reactions are:

$$
\begin{aligned}
& 3 \mathrm{Mg}+\mathrm{Al}_{2} \mathrm{O}_{3} \rightarrow 3 \mathrm{MgO}+2 \mathrm{Al}, \\
& \mathrm{MgO}+\mathrm{Al}_{2} \mathrm{O}_{3} \rightarrow \mathrm{MgAl}_{2} \mathrm{O}_{4} .
\end{aligned}
$$

$\mathrm{Mg}$ also improves the wetting between $\mathrm{Al}$ and $\mathrm{SiC}$ particles by reducing the $\mathrm{SiO}_{2}$ layer on the surface of $\mathrm{SiC}$ and aiding in removal of $\mathrm{Al}_{2} \mathrm{O}_{3}$ film on $\mathrm{Al}$ melt. The reaction is (Quigley et al 1982):

$$
4 \mathrm{Mg}+\mathrm{SiO}_{2} \rightarrow \mathrm{Mg}_{2} \mathrm{Si}+2 \mathrm{MgO}
$$

Table 3. Table showing variation in critical strain to interface cavity formation, contact angle and work of adhesion with alloying elements in a $\mathrm{Fe}-$ alloy $/ \mathrm{Al}_{2} \mathrm{O}_{3}$ composite (Easterling et al 1973).

\begin{tabular}{lccc}
\hline Matrix & $\varepsilon_{c}$ & $\theta($ degrees $)$ & $W\left(\mathrm{mJm}^{-2}\right)$ \\
\hline $\mathrm{Fe}-40 \mathrm{Ni}$ & 0.05 & $<10$ & 44 \\
$\mathrm{Fe}-40 \mathrm{Ni}-5 \mathrm{Cr}$ & 0.05 & 16 & 112 \\
$\mathrm{Fe}-40 \mathrm{Ni}-5 \mathrm{Mn}$ & 0.10 & 15 & 99 \\
$\mathrm{Fe}-40 \mathrm{Ni}-5 \mathrm{Mo}$ & 0.15 & 65 & 1674 \\
$\mathrm{Fe}-1 \mathrm{Ti}$ & & 35 & 524 \\
$\mathrm{Fe}-10 \mathrm{Co}$ & 0.08 & 60 & 1450 \\
$\mathrm{Fe}-5 \mathrm{Cr}$ & 0.10 & 80 & 2397 \\
\hline
\end{tabular}


It has been reported by Sritharan et al (1990) that ideal matrices for SiC reinforcement, which show the maximum strengthening effect, are high $\mathrm{Mg}$-containing $5 \mathrm{XXX}$ and $6 \mathrm{XXX}$ alloys as more of $\mathrm{Mg}_{2}$ Si can be precipitated. On the other hand, reduction in strength has been reported in case of $\mathrm{Al}-\mathrm{Cu}-\mathrm{Mg}$ alloys (with respect to monolithic alloy) as $\mathrm{Mg}$ segregation at interfaces results in the depletion of $\mathrm{Mg}$ content in the matrix. Similar lowering of strength is reported for $7 \mathrm{XXX}$ alloys as $\mathrm{Mg}$ content is depleted by formation of $\mathrm{MgZn}_{2}$ and $\mathrm{Mg}_{2}$ Si at the interfaces. In certain other studies, addition of $\mathrm{Mg}$ to $\mathrm{Al}-\mathrm{SiC}$ composites has proved to be detrimental due to formation of Mg-rich amorphous region (Nutt and Carpenter 1985; Nutt 1986), or intermetallic precipitates like CuMgAl (Nutt and Carpenter 1985; Bhanuprasad 1991) at the interface. In cast alloy-matrix MMCs, coarse intermetallic particles are quite often seen at the interfaces because the residual melt enriched in solute solidifies near poorly heat-conducting ceramic reinforcement.

Other than $\mathrm{Mg}$, $\mathrm{Li}$ has been successfully used as an alloying element to enhance the wetting between $\mathrm{Al}$ and $\mathrm{Al}_{2} \mathrm{O}_{3}$ (Dhingra 1980) and $\mathrm{SiC}$ (Webster 1982) reinforcements. The mechanism is similar to that of $\mathrm{Mg}$, that is reduction of oxide layers at the interface, which otherwise prevents direct contact between Al and the ceramic reinforcement. Webster (1982) has systematically investigated the effect of $\mathrm{Li}$ additions $(3-5 \%)$ to $\mathrm{Al}$ on mechanical properties of $\mathrm{Al} / \mathrm{SiC}_{w}$ composites. Strengthening effect was significantly enhanced by additions of $\mathrm{Li}$ as shown in table 4 and this has been attributed to increase in the matrix-reinforcement bond strength. $\mathrm{Li}$ increases the reactivity of $\mathrm{Al}$ and as a consequence promotes its interaction with $\mathrm{SiC}$ at the interface. Thus Young's modulus values were close to those predicted by the rule of mixtures. No chemical reaction product could be observed at the interface using TEM. Alloying with indium, lead and thallium has improved wetting between $\mathrm{Al}$ and carbon fibres by reducing the surface tension of liquid metal (Kimura et al 1984). However, to our knowledge these have not been studied for $\mathrm{Al} / \mathrm{SiC}$ composites. Mcdonald and Ransley (1954) observed that addition of $\mathrm{Ni}$ or Co to Al improved the wettability of $\mathrm{Al} / \mathrm{TiC}$ system.

Effect of matrix on bond integrity can also be appreciated by analysing the modulus values of $\mathrm{Mg} / \mathrm{SiC}$ and $\mathrm{Al} / \mathrm{SiC}$ metal matrix composites. Figure 9 is a comparison between $E(\operatorname{expt}) / E(\mathrm{ROM})$ of $\mathrm{P} / \mathrm{M} \mathrm{Mg} / \mathrm{SiC}$ (Skinner et al 1990) and that of $\mathrm{P} / \mathrm{M}$ $\mathrm{Al} / \mathrm{SiC}$, where the matrices are commercially pure metals. It is evident that the $\mathrm{Mg} / \mathrm{SiC}$ composite has smaller value of the ratio compared to the $\mathrm{Al} / \mathrm{SiC}$ composite, indicating that the interfacial bond is stronger in the latter. The possible reason is matrix-reinforcement chemical interaction is stronger in the latter as Al forms a stable carbide as well as alloys with Si.

Table 4. Variation in Young's modulus with addition of $\mathrm{Li}$ to $\mathrm{Al} / \mathrm{SiC}_{\mathrm{w}}$ composites based on Webster's data (Webster 1982).

\begin{tabular}{lrc}
\hline Matrix & Modulus (GPa) & $\begin{array}{r}\text { \% Increase with } \\
\text { respect to matrix }\end{array}$ \\
\hline $\mathrm{Al}$ & 70 & \\
$6061-\mathrm{Al}+20 \% \mathrm{SiC}_{\mathrm{w}}$ & 100 & 43.0 \\
$\mathrm{Al}+3 \cdot 5 \% \mathrm{Li}$ & 86 & $62 \cdot 0$ \\
$\mathrm{Al}+3 \cdot 5 \% \mathrm{Li}+20.9 \mathrm{SiC}_{\mathrm{w}}$ & 139 & 6 \\
\hline
\end{tabular}




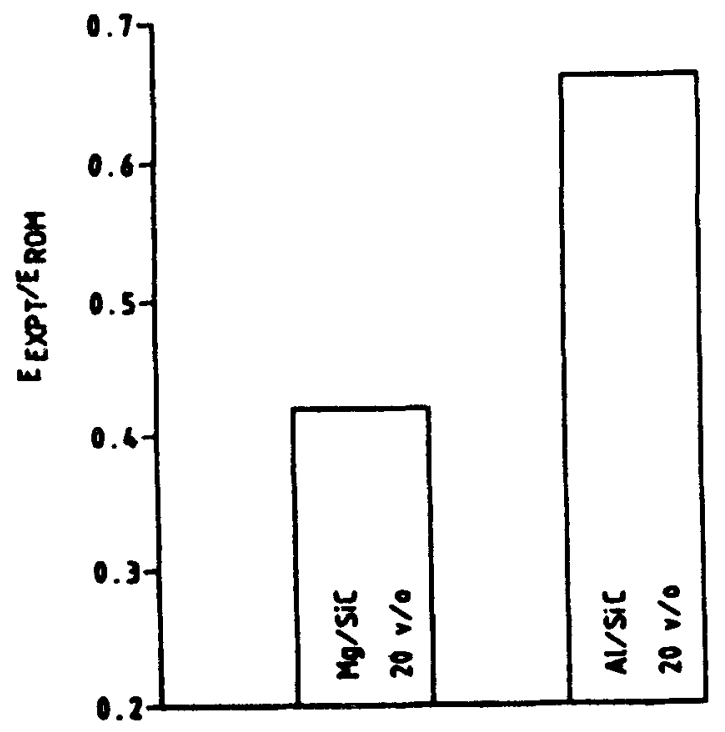

Figure 9. Comparison between $E($ expt $) / E(\mathrm{ROM})$ ratios of $\mathrm{Mg} / 20 \mathrm{v} / \mathrm{o} \mathrm{SiC}$ and $\mathrm{Al} / 20 \mathrm{v} / \mathrm{o} \mathrm{SiC}$ (Schroder et al 1991) metal matrix composites.

\section{Effect of processing: Conventional and in situ processing}

Processing variables play a very significant role in control of interfacial characteristics. Based on processing, composites can be classified as 'conventional' or 'in situ'. 'Conventional' composites are those which are prepared by powder metallurgy routes, which involves blending of matrix and reinforcement powders followed by cold compaction and hot pressing or casting routes. The flowchart in figure 10 shows the process developed and followed at DMRL. Hot pressing is carried out in two steps, the first being above solidus and for a short duration and the next for longer time below the solidus. Without a liquid phase formed during hot pressing or sintering, high modulus values are not achievable (Mcdonald and Ransley 1954). The mechanisms of bonding in absence of a liquid phase are mechanical interlocking of particles and solid-state diffusion leading to a chemical bond.

In casting route, conventional composites are fabricated by adding reinforcements to molten metal and distributing ușing a stirrer, or rheocasting or melt infiltration to ceramic preform or green compact by liquid metal. Higher processing temperature may promote wetting in many cases, but often leads to degradation of reinforcements by chemical reactions as is observed in Al-SiC system. Chiou and Chung (1990) prepared $\mathrm{Al} / \mathrm{SiC}$ composite by infiltration of liquid $\mathrm{Al}$ into a porous preform of $\mathrm{SiC}$ whiskers in vacuum under inert gas pressure at $665^{\circ} \mathrm{C}, 690^{\circ} \mathrm{C}$ and $720^{\circ} \mathrm{C}$ and observed that tensile strength, Young's modulus, as well as the extent of elongation decreased with increase in processing temperature. Also, significant whisker pullout could be observed during tensile failure of the composites prepared at higher temperature. All this is attributed to formation of brittle reaction product $\mathrm{Al}_{4} \mathrm{C}_{3}$ formed at the interface.

Sometimes processing in certain temperature ranges can only lead to chemical reactions between matrix and reinforcement. For example, $\mathrm{Al}$ and $\mathrm{TiC}$ react as 


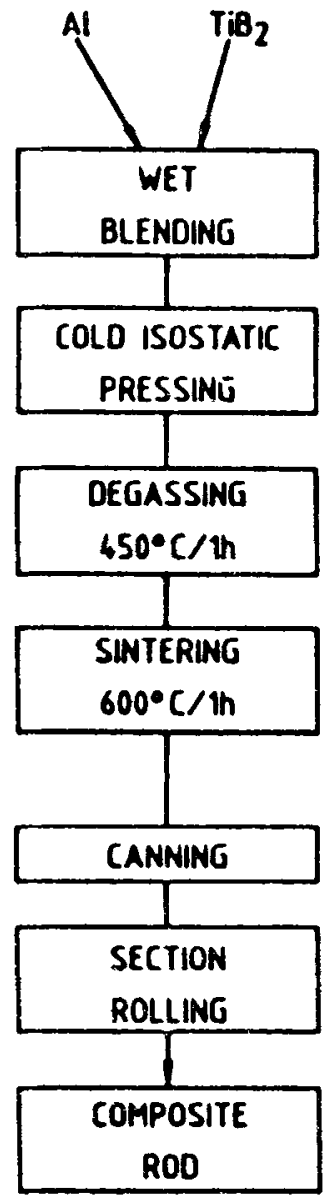

(a)

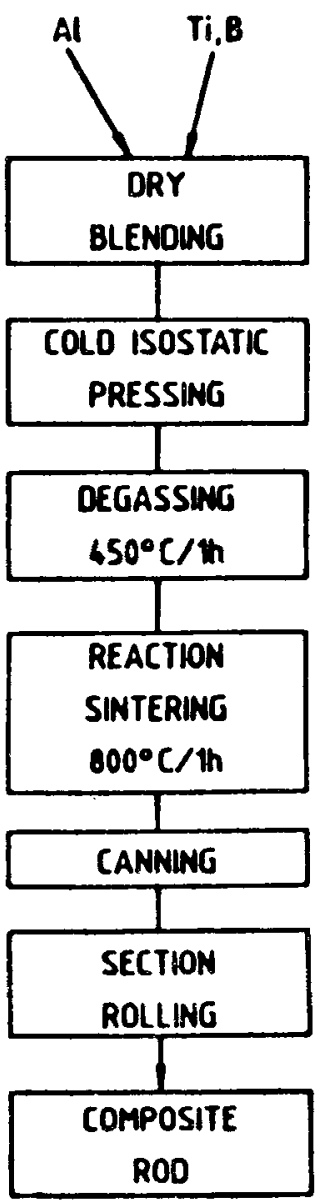

(b)

Figure 10. Flowchart showing conventional $P / M$ and $X D$ process developed at DMRL for preparing metal matrix composites.

(Satyaprasad et al 1992; Mitra et al 1992a, 1993a)

$$
13 \mathrm{Al}+3 \mathrm{TiC} \rightarrow 3 \mathrm{Al}_{3} \mathrm{Ti}+\mathrm{Al}_{4} \mathrm{C}_{3},
$$

at temperatures below $752^{\circ} \mathrm{C}$, above which the free energy of formation is positive and the chemical reaction is not feasible. Extent of chemical reaction also varies with time and a systematic study has been performed for Al-TiC (Mitra et al 1992b, 1993a) and Al-SiC (Lloyd and Jin 1988).

It has been discussed in the earlier section that coarse intermetallic particles precipitate at the matrix-reinforcement interface in MMCs prepared by casting as the solute-rich residual melt solidifies at the interface towards the end. However, in MMCs prepared by spray deposition (White et al 1983) TEM investigations have shown clean interfaces with negligible precipitation. This can obviously be explained 
on the basis of the fact that contact time between liquid matrix phase and reinforcement is of the order of a few seconds in spray deposition processing and a few minutes in case of squeeze casting. Thus in $\mathrm{Al}$-alloy composites prepared by spray deposition attractive combination of strength and modulus could be achieved because of excellent bond integrity.

In the above processing techniques, reinforcement particles or whiskers are prepared in a separate process before processing of the composites. During this or subsequent handling, the surfaces of the particles pick up impurities or get oxidized, and continue as a third continuous or discontinuous phase at the interface. XPS studies on isolated $\mathrm{Si}_{3} \mathrm{~N}_{4}$ whiskers have shown $\mathrm{Si}_{2} \mathrm{~N}_{2} \mathrm{O}$ and oxygen impurities (Homeny et al 1990). $\mathrm{SiO}_{2}$ has also been observed on the $\mathrm{SiC}$ whisker surfaces using XPS (Date 1994). These oxide layers participate in interfacial reactions during processing of MMCs and interface chemistry becomes complex. The interface in these cases fails to reach the state of thermodynamic equilibrium. Amorphous oxide layers often found at interfaces (Nutt and Carpenter 1985; Nutt 1986; Ning et al 1992) are responsible for interfacial void formation or cracking during external loading at room and elevated temperatures (Marcus and Rabenberg 1987; Ribes et al 1990; Xia et al 1990).

Amorphous phase ( $7-30 \mathrm{~nm})$ has also been noticed at diffusion-bonded pure $\mathrm{Al} / \mathrm{SiC}$ interface by Ratnaparkhi and Howe (1992). Auger studies have revealed that this region is enriched in $\mathrm{Al}, \mathrm{Si}, \mathrm{C}$ and $\mathrm{O}$ and there is diffusion of $\mathrm{Al}$ and $\mathrm{O}$ into the highly strained region of $\mathrm{SiC}$, immediately adjacent to the interface. However, there is no evidence of $\mathrm{C}$ or Si diffusion into $\mathrm{Al}$. This amorphous phase could have originated from solidification of $\mathrm{Al}-\mathrm{Si}-\mathrm{C}-\mathrm{O}$ eutectic liquid at the interface. But in situ hot-stage microscopy, where specimen was reheated to $650^{\circ} \mathrm{C}$, did not show any mechanical instability in the region, proving that a solid-state reaction was responsible for formation of amorphous region during processing.

Figure 11 shows a typical interface in $\mathrm{MoSi}_{2} / \mathrm{SiC}$ composite containing an amorphous phase 5-8 nm thick. This composite was fabricated at DMRL, Hyderabad, by hot-pressing an intimate mixture of elemental $\mathrm{Mo}+\mathrm{Si}$ (stoichiometric ratio) and $\mathrm{SiC}$ powders in vacuum, where $\mathrm{Mo}$ and $\mathrm{Si}$ react to form $\mathrm{MoSi}_{2}$ in situ. SiC was HF-treated to remove $\mathrm{SiO}_{2}$. The composition of amorphous region is under investigation. Such amorphous regions at the matrix-reinforcement interfaces have also been noticed in $\mathrm{XD} \mathrm{MoSi}_{2} / \mathrm{SiC}$ composite (Suzuki et al 1993) as well as $\mathrm{RBSC}-\mathrm{MoSi}_{2}$ composites (Lim et al 1989).

In a recent review, Arsenault (1994) has reported the absence of orientation relationships in nonequilibrium interfaces or those with amorphous areas. This is common in composites fabricated by conventional $\mathrm{P} / \mathrm{M}$ processes. For example, Radmilovic et al (1991) did not observe any preferred orientation relationship in 2014 $\mathrm{Al} / \mathrm{SiC}$ composites fabricated by conventional $\mathrm{P} / \mathrm{M}$ process. This is similar to the observations of Van Den Burg and De Hosson (1992). However in case of P/M 6061 $\mathrm{Al} / \mathrm{SiC}$ composites, Van Den Burg and De Hosson noticed a preferred orientation relationship of $(0001)_{\mathrm{SiC}} / /\{111\}_{\mathrm{A} 1}$ and $\langle 2110\rangle_{\mathrm{SiC}} / /\langle 110\rangle_{\mathrm{Al}}$. In cast composites, a consistent orientation relationship could be seen (Arsenault 1994; Weimin et al 1991):

$$
[11 \overline{2} 0]_{\mathrm{SiC}} / /[110]_{\mathrm{A} 1} \text { and }(0001)_{\mathrm{SiC}} / /(112)_{\mathrm{A} 1} \text {. }
$$

A variant relationship $[1120]_{\mathrm{SiC}} / /[110]_{\mathrm{Al}},(01 \overline{1} 0)_{\mathrm{SiC}} / /(111)_{\mathrm{Al}}$ has also been observed. In all cases (Arsenault 1994), (111) Al planes are aligned either perpendicular or at $70^{\circ}$ to 


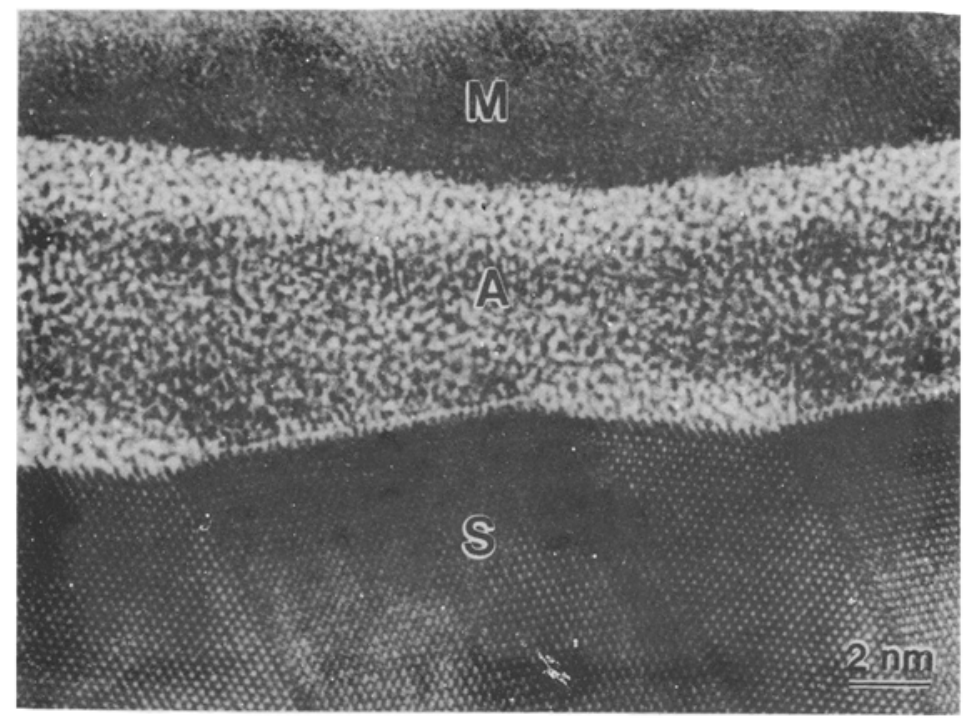

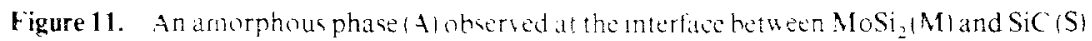
in the MoS! 2010 SiC compoute Mitra e't al 19951 .

the interfacial axis when the $\mathrm{SiC}$ basal planes are perpendicular to the interfacial axis. If $\mathrm{SiC}$ basal planes are parallel to the interfacial axis the $1111 \mathrm{Al}$ planes are oriented at 20 to the intefface Again in contrast to ubervations in P M 2014 Al SiC composite. Carim could observe an orientation relationship of $\left.(1001)_{S_{1} C} \quad 1557\right)_{4 i}$ in cast 2014 Al SiC composites. In P M processes, without a liquid phase, the particles bonded together are randomly oriented leading to noncquilibrium and high-energy interfaces. In cast composites, there is a tendency for the liquid metal to solidify forming low-energy interfaces. This explains further the need for liquid phase in P $M$ processing, such as hot pressing.

Back in 1954. Medonald and Ransley (1954) through a series of investigations found that incorporation of high-modulus dispersonds in Al matrices resulted in moduli less than that of the matrux by itself. It was obvous that increase of dispersoid content fails to affect the modulus. On the other hand. wetting look place automatically if the high-modulus phase was an intermetallic compound precipitated in situ by reaction between elements" and the same was difficult to induce by mechanical mixing of powders and purely solid-state processing. This is because the composites prepared by in situ processing have clean interfaces as the chemical reaction between elements to produce the dispersoid takes place inside the solid or liquid metal. Some of the in situ processing techniques involving molien metal and developed in recent years are XD (exothermic dispersoidi developed at Martin Manetta Laboratory, Baltimore, USA (Westwood 1988) and gas injection process developed by Koczak at Drexel Lniversity. Philadelphia. LSA (Koczak and Kumar 1989). Similariy, solid-state processing techniques like internal oxidation or reduction (Mader 19921 and displacement reactions (Henager er al 1992) have also been developed. Solid-state in situ processes normally lead to second-phase precipttates with an equilibrium low-energy orientation relationship with respect to the matrix and interfaces can show varying degrees of 
coherency based on lattice misfit and strength of interaction between the matrix and the reinforcement (Mader 1992).

Atomic-resolution TEM studies of the interface between Al matrix and TiC particle in $\mathrm{XD} \mathrm{Al} / \mathrm{TiC}$ composite have proved that interface is abrupt on an atomic scale (figures 6 and 7) (Mitra et al 1993b). No impurities or sign of oxidation of particle surfaces could be seen by EDS and EELS at the interface. This is possible only because the particles were precipitated in situ, which prevents them from contamination.

EDS using a probe size of $3 \mathrm{~nm}$ (including effect of beam broadening) was used to investigate the interface in $\mathrm{XD} 2024 \mathrm{Al} / \mathrm{TiB}_{2}$ composite in a field emission analytical TEM (Mitra et al 1993b). No segregation of $\mathrm{Mg}$ or $\mathrm{Cu}$ alloying elements could be found near the interface. This suggests that the interfaces formed are of sufficiently lower energy, and there is little driving force for interfacial segregation.

Apart from the fact that the interfaces are clean, some other interesting features are associated with the XD composites. Many of the $\mathrm{Al} / \mathrm{TiC}$ interfaces in $0.7 \mu \mathrm{m}$ particle $\mathrm{XD}$ composite (cast and extruded at a ratio of $27: 1$ at $375^{\circ} \mathrm{C}$ ) were semicoherent and showed localized strain contrast in the TEM (Mitra et al 1993b). Figure 12a is a bright-field TEM micrograph of a semicoherent $\mathrm{Al} / \mathrm{TiC}$ interface, where interface dislocations and facets can be seen. Figure $12 \mathrm{~b}$ is a weak-beam dark-field TEM image of an $\mathrm{Al} / \mathrm{TiC}$ interface showing misfit strain localization. Normally, particles which were finer and located inside $\mathrm{Al}$ grains and surrounded by some Al subgrains had semicoherent interfaces. On cold rolling to $75 \%$ of its original thickness followed by annealing, the material recrystallized leading to a microstructure in which faces of the

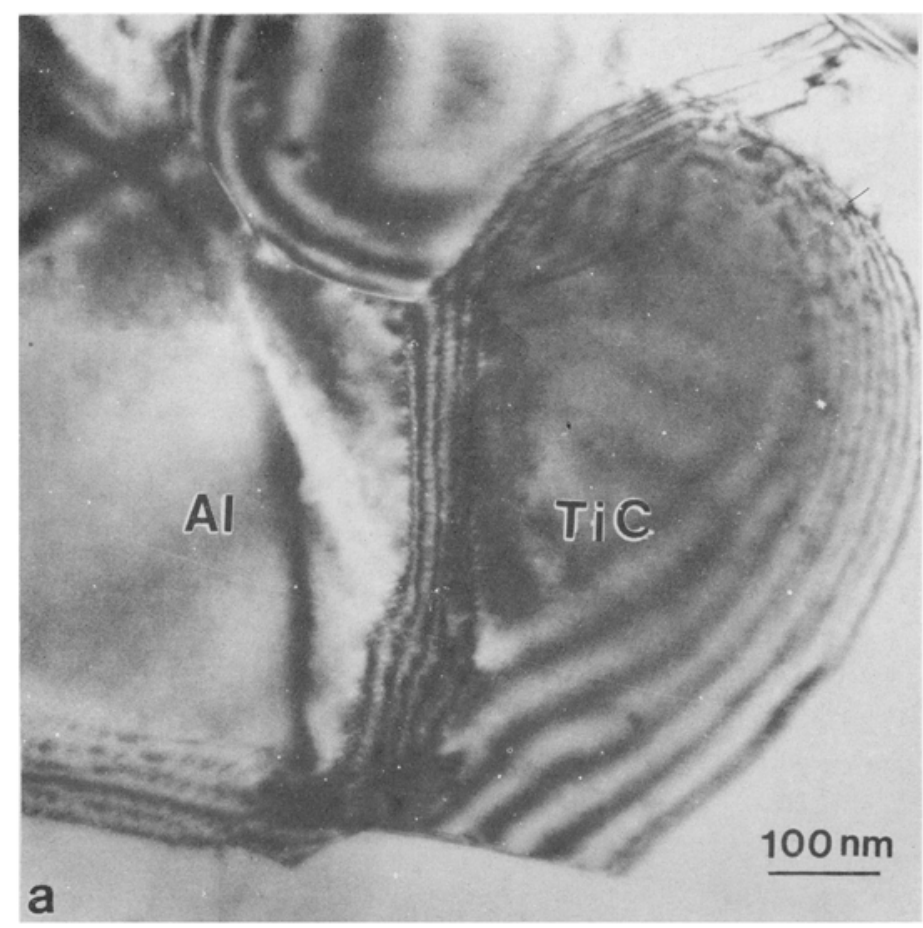

Figure 12a. 


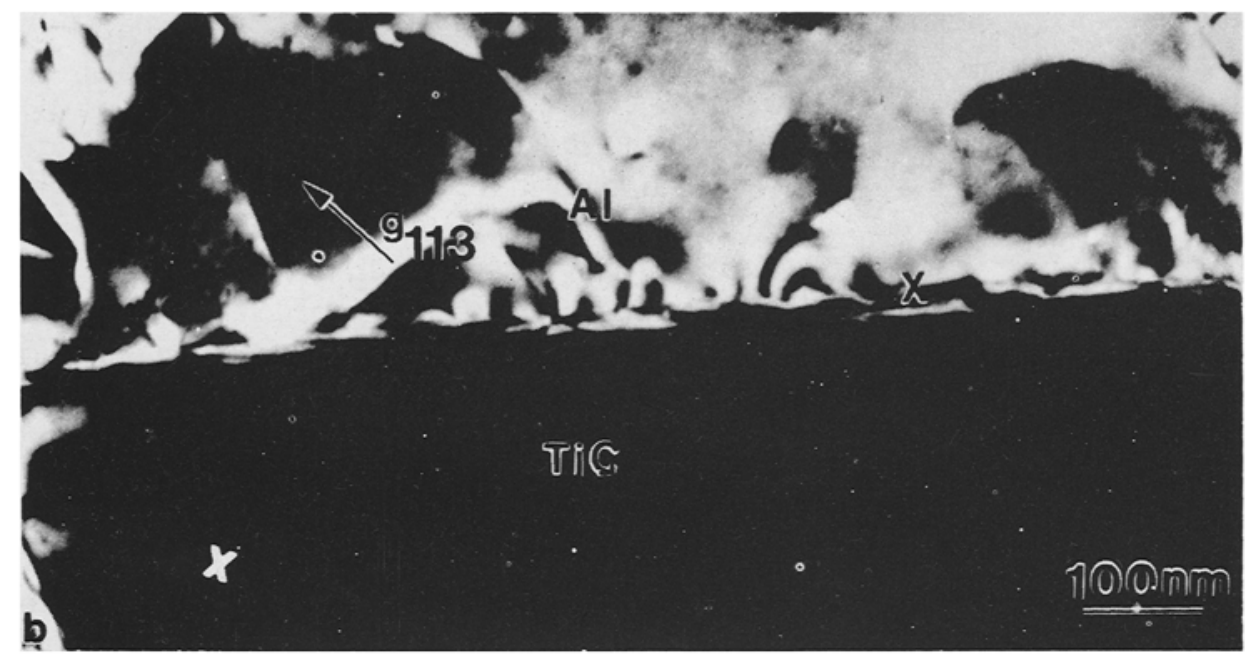

Figure 12. TEM micrographs of at semwoherent interfacio in cast and extruded XD Al TiC composite (Mitra et al 1993b). (a) Bright-tield image and (b) weak-beam dark-tield image of a different particle matrix interface ' $X$.' Misfit stran contrast can be distinguished.

TiC particles were surrounded by one or more subgrains (Mitra et al 1992a: Fine at al 1993). The interfaces between these and $\mathrm{TiC}$ particles were in most cases semicoherent with misfit strain localization (figure 13). As shown in figure 5, interfaces were always parallel to ;111) TiC planes. In another investigation. Wang and Arsenault (1991) observed that the $\mathrm{NiAl}: \mathrm{Al}_{2} \mathrm{O}_{3}$ interfaces in $\mathrm{XD} \mathrm{NiAl} \mathrm{Al}_{2} \mathrm{O}_{3}, \mathrm{TiB}$, composites were semicoherent and showed misfit localization. Presence of semicoherency of course supports the idea that particle-matrix is strong in XD composites, where there is direct contact between the atoms of the two phases.

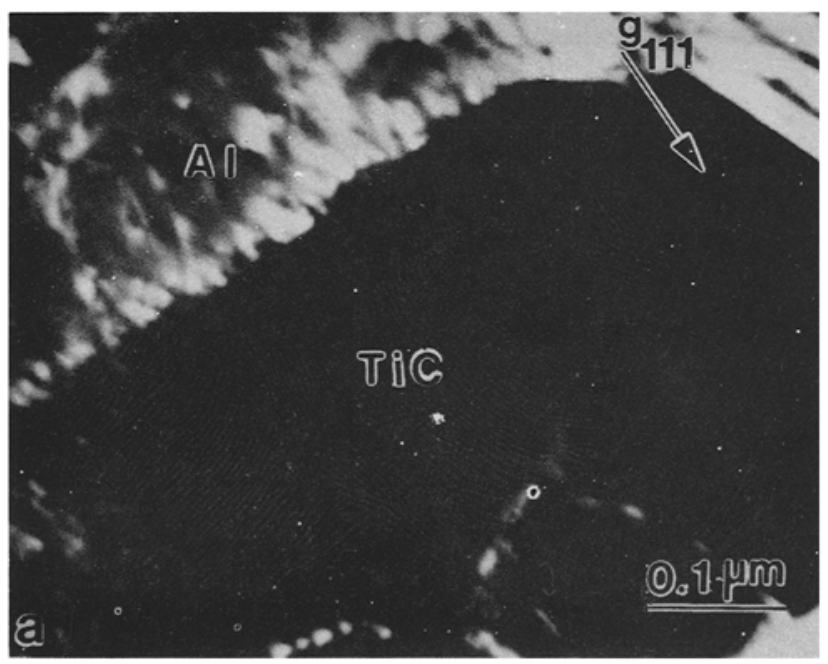

Figure 13a. 


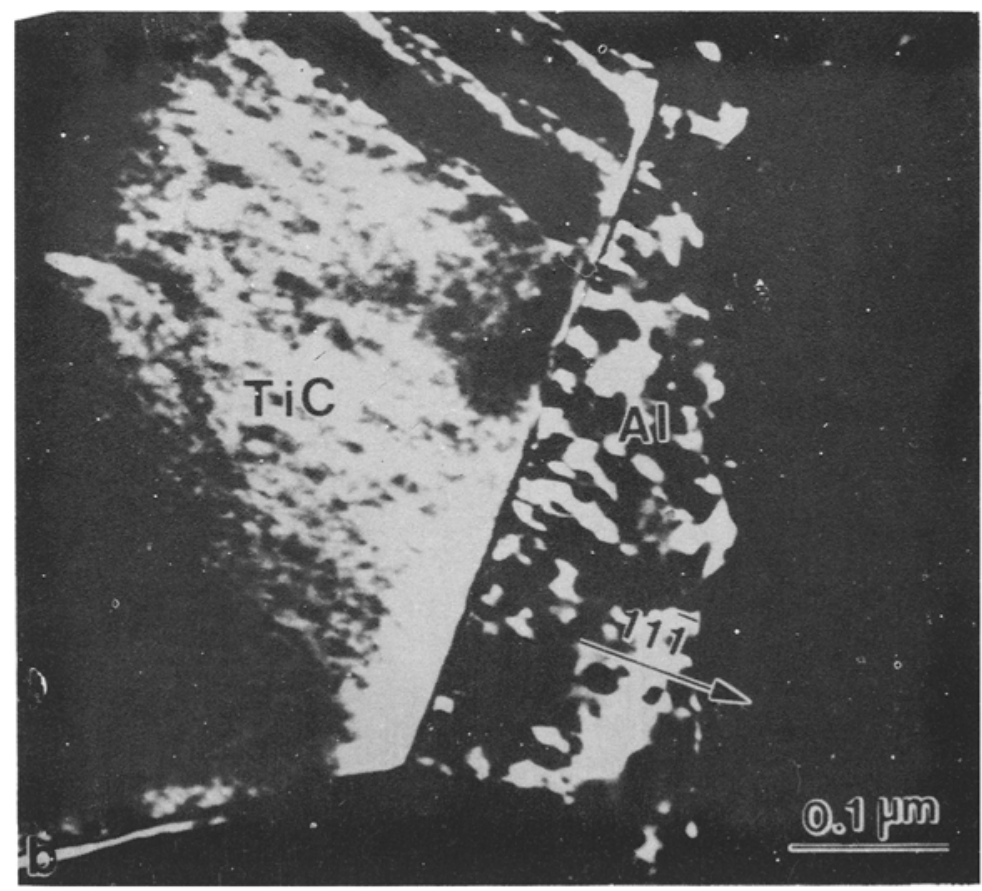

Figure 13. a -b. Dark-field TEM micrograph of a semicoherent interface between an Al subgrain and $\mathrm{TiC}$ particle in the $\mathrm{XD} \mathrm{Al} / \mathrm{TiC}$ composite. The composite was cold-rolled and annealed for recrystallization (Mitra 1993). Interface dislocations can be seen.

In situ composites have consistently shown higher modulus compared to those prepared by conventional techniques like casting and powder metallurgy (Westwood and Winzer 1987; Kuruvilla et al 1990). Young's modulus of $\mathrm{Al} / \mathrm{TiB}_{2}$ prepared by XD process a: DMRL. Hyderabad (Kuruvilla et al 1990) is much higher as is clear from the bar chart for $E$ (expt)/E(ROM) shown in figure 14. Young modulus value of 15 vol\% XD Al/ $\mathrm{TiC}$ was found to be $94 \mathrm{GPa}$ (Mirra et al 1993b), which is well within the lower and upper limits provided by Hashin-Shtrikman model (Hashin and Shtrikman 1963।. Similar observations were made by Aikin for $15 \mathrm{vol} \% \mathrm{XD} \mathrm{Al} / \mathrm{TiB}_{2}$ (Aikin 1989). A significant improvement in Young's modulus over the monolithic metal or alloy is achievable mainly because of excellent chemical bond between atoms of metal and the reinforcement which are again in direct contact as has been seen in $\mathrm{XD} \mathrm{Al} / \mathrm{TiC}$.

\section{Effect of ageing and heat treatment}

Ageing heat treatments in $7 \mathrm{XXX}$ and $2 \mathrm{XXX} \mathrm{Al-SiC}$ composites. particularly the former, siznificantly alter the structure and chemistry of the interface (Manoharan and Lewandowski 1989). Interfacial segregation of $\mathrm{Cu}, \mathrm{Mg}$ or $\mathrm{Zn}$ could be seen in both underaged as well as overaged conditions. In underaged $2 \mathrm{XXX}$ matrix composite. the region of segregation was in the form of a diffuse layer $20 \mathrm{~nm}$ into the matrix from the interface. The profiles of $\mathrm{Mg}$ and $\mathrm{Cu}$ were fairly broad and peaked away from the 


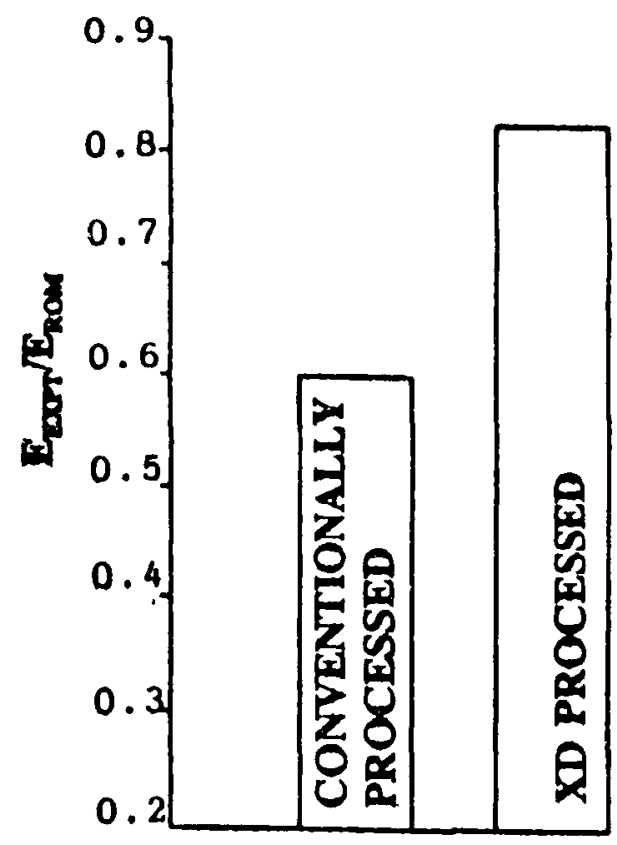

Figure 14. Comparison of $E$ (expt)/E(ROM) ratios of $\mathrm{Al} / \mathrm{TiB}_{2}$ composites prepared by conventional $\mathrm{P} / \mathrm{M}$ and XD process (Kuruvilla et al 1990). It is clear that the latter has higher modulus.

Table 5. Effect of isothermal annealing treatment $\left(600^{\circ} \mathrm{C}\right)$ on tensile ductility of Al matrix composites.

\begin{tabular}{|c|c|c|c|}
\hline \multirow[b]{2}{*}{ Material } & \multirow{2}{*}{$\begin{array}{l}\text { Time exposure } \\
\text { (hours) }\end{array}$} & \multicolumn{2}{|c|}{$\%$ Elongation } \\
\hline & & Initial & After exposure \\
\hline $\mathrm{Al} / 20 \mathrm{v} / \mathrm{oB}_{4} \mathrm{C}^{*}$ & 48 & $9 \cdot 0$ & 2.5 \\
\hline $\mathrm{Al} / 20 \mathrm{v} / \mathrm{o} \mathrm{TiC}^{*}$ & 96 & 68 & 0.8 \\
\hline $\mathrm{Al} / 20 \mathrm{v} / \mathrm{o} \mathrm{SiC} * *$ & 96 & $10 \cdot 0$ & $4 \cdot 0$ \\
\hline $\mathrm{Al} / 20 \mathrm{v} / \mathrm{o} \mathrm{TiB}_{2}{ }^{* *}$ & 100 & $12 \cdot 2$ & $12 \cdot 2$ \\
\hline
\end{tabular}

*Vigorous reaction

**No reaction

interface because of nonequilibrium segregation of vacancies. However, after overaging, vacancies were segregated at the interface to meet the equilibrium conditions and the peak shifted to the interface. Similarly, a diffuse interface precipitate layer $10-$ $20 \mathrm{~nm}$ wide was seen near the interface. On overaging, fairly regularly spaced particles $\mathrm{Mg}_{32}(\mathrm{Al}, \mathrm{Zn})_{49}$ appeared with a distinct PFZ next to them extending $35-40 \mathrm{~nm}$ in the matrix, which is depleted in solute. In response to equilibrium vacancy segregation at the interface, there is a decrease in their concentration in the region where PFZ forms as solute atoms migrate by diffusion and segregate at the interface.

Recently, isothermal heat treatment of $\mathrm{Al} \mathrm{MMCs}$ containing $20 \mathrm{vol} \% \mathrm{SiC}, \mathrm{TiB}_{2}$, $\mathrm{B}_{4} \mathrm{C}$ or TiC was performed at $600^{\circ} \mathrm{C}$ for different periods of time, and the results are shown in table 5 (Satyaprasad and Mahajan 1994). $\mathrm{TiB}_{2}$ is thermodynamically stable 
Table 6. Effect of heat treatment at $600^{\circ} \mathrm{C}$ for $96 \mathrm{~h}$ on properties of $\mathrm{Al} / \mathrm{SiC}$ and $\mathrm{Al} / \mathrm{TiB}_{2}$ composites (Satyaprasad and Mahajan 1994).

\begin{tabular}{|c|c|c|c|c|}
\hline \multirow[b]{2}{*}{ Material } & \multicolumn{2}{|c|}{ Young's modulus (GPa) } & \multicolumn{2}{|c|}{ Yield strength (MPa) } \\
\hline & Initial & Heat-treated & Initial & Heat-treated \\
\hline $\mathrm{Al} / 20 \mathrm{v} / \mathrm{O} \mathrm{SiC}$ & $97 \cdot 5$ & 100 & 115 & 190 \\
\hline $\mathrm{Al} / 20 \mathrm{v} / \mathrm{o} \mathrm{TiB}_{2}$ & & & 105 & 121 \\
\hline
\end{tabular}

in $\mathrm{Al}$ at $600^{\circ} \mathrm{C}$ and obviously the elongation properties are not affected. $\mathrm{TiC}$ and $\mathrm{B}_{4} \mathrm{C}$ react extensively with $\mathrm{Al}$ resulting in reaction products at the interface $\left(\mathrm{Al}_{3} \mathrm{Ti}\right.$ and $\mathrm{Al}_{4} \mathrm{C}_{3}$ in case of $\mathrm{TiC}$ and $\mathrm{Al}_{4} \mathrm{C}_{3}$ and $\mathrm{AlB}$ in case of $\mathrm{B}_{4} \mathrm{C}$ ), which adversely affects tensile ductility. $\mathrm{Al} / \mathrm{SiC}$ composite also shows lower elongation after heat treating and this is surprising as no reaction product could be seen at the interface using conventional TEM. However, some discontinuous precipitates of $\mathrm{MgO}$ and $\mathrm{MgAl}_{2} \mathrm{O}_{4}$ could be seen, which possibly originated from $\mathrm{Mg}$ impurities in the matrix. $\mathrm{Al} / \mathrm{SiC}$ also showed some changes in Young's modulus and a significant change in yield strength after heat treating as shown in table 6 . This suggests strengthening of the interfacial bond during heat treatment. It appears that at a temperature of $600^{\circ} \mathrm{C}\left(0.94 T_{\mathrm{m}}\right)$ where diffusivity of $\mathrm{Al}$ is large, rearrangement on an atomic scale is possible near the interface leading to a structure closer to equilibrium. Slight but quite noticeable increase could be seen in the yield strengths of the $\mathrm{Al} / \mathrm{TiB}_{2}$ composite also (table 6). A detailed investigation of the interface is necessary to explain this. Recently, Warner and Stobbs (1989) noticed an increase in elastic modulus in $\mathrm{Al}-1.9 \% \mathrm{Mg} / 14 \mathrm{v} / \mathrm{o} \mathrm{SiC} p$ composite on isothermal heat treatment, with the $0.2 \%$ yield stress remaining unchanged. Wu and Lavernia (1991) on the other hand, saw noticeable increase in yield and ultimate tensile strength of the MMCs prepared by spray deposition process on annealing at $560^{\circ} \mathrm{C}$ for $22 \mathrm{~h}$ prior to extrusion. It was observed that the failure mechanism involved fracture of SiC particles, rather than pull-out. This was explained based on the fact that annealing helped in improving the bond strength between matrix and reinforcement. Interdiffusion between $\mathrm{Al}$ and $\mathrm{SiC}$ was suggested as the reason for increase in bond strength. This was noticed earlier by Arsenault (1984).

\section{Influence of the interface on physical properties}

Interfaces play a significant role in determination of the physical and mechanical properties of the composite. The physical properties include coefficient of thermal expansion, thermal conductivity and damping.

Coefficient of thermal expansion is an important criterion for the design of dimensionally stable composites. Recently, the coefficients of thermal expansion were measured for $15 \mathrm{vol} \% \mathrm{XD} \mathrm{Al} / \mathrm{TiC}$ composite with 0.7 or $4.0 \mu \mathrm{m}$ particle size and it was observed that the former had smaller coefficient of thermal expansion (Xu et al 1994). The matrix being pure $\mathrm{Al}$ in either situation, it is surely due to more interface area in smaller-particle-size composite. The lattice distortion observed close to the matrixreinforcement interfaces in XD Al/TiC (Mitra et al 1993b) has been suggested to alter the behaviour of the interface with respect to thermal expansion. The coeffieient of 
thermal expansion of the composite $\alpha_{c}$ can be expressed as

$$
\alpha_{\mathrm{c}}=\alpha_{\mathrm{p}} V_{\mathrm{p}}+\alpha_{\mathrm{m}} V_{\mathrm{m}}+\alpha_{\mathrm{i}} V_{\mathrm{i}}
$$

where $\alpha_{p}, \alpha_{m}$ and $\alpha_{i}$ are coefficients of thermal expansion of particle, matrix and interfaces respectively, and $V_{\mathrm{p}}, V_{\mathrm{m}}$ and $V_{\mathrm{i}}$ are volume fractions of particle, matrix and interfaces. $\alpha_{i}$ can be determined indirectly by using (6) for curve-fitting with the experimental data.

Hasselman and Donaldson (1992) reported thermal conductivity in $\mathrm{Al} / \mathrm{SiC}$ metal matrix composites for particle sizes varying between 0.7 and $28 \mu \mathrm{m}$. It was observed that thermal conductivity decreased with smaller particle size. This phenomenon can again be explained based on the fact that finer-particle-size composite has larger interface area. The interface acts as a thermal barrier. Thus for maximizing thermal conductivity, particle size needed is the largest possible as this will reduce the total interface area. Geiger et al (1993) observed that $6090 \mathrm{Al} / \mathrm{SiC}$ composites with $10 \cdot 2$ and $28 \mu \mathrm{m}$ particles had higher thermal conductivity than that of the unreinforced matrix. This was possible probably due to excellent bonding. However, with decrease in SiC particle size, thermal conductivity of the composite fell. Geiger and Jackson (1989) have also reported that $6061 \mathrm{Al} / \mathrm{SiC}$ shows higher thermal conductivity than 2124 $\mathrm{Al} / \mathrm{SiC}$. Besides the interface, the temper of the matrix alloy also affects the thermal conductivity and thus the above is difficult to explain.

Interfaces with reaction products or precipitates are likely to act as stronger barriers to heat conductivity than cleaner ones. This was investigated in detail by Reeves et al (1987) for the case of $\mathrm{Ti} / \mathrm{SiC}$ composites, where the reaction products were a mixture of $\mathrm{TiC}$ and $\mathrm{Ti}_{5} \mathrm{Si}_{3}$. For a reaction layer of $0.5 \mu \mathrm{m}$ or thinner, the thermal conduciivity of the composite was similar to that of the unreinforced matrix. This could be due to the fact that $\mathrm{SiC}$ particles possessed lower thermal conductivity than typical dense bulk $\mathrm{SiC}$ or because of the barrier created by the reaction layer. If the reaction layer was relatively thick (greater than $1 \mu \mathrm{m}$ ), thermal conductivity values of the composite were markedly reduced. The values were below those expected for composites reinforced with similar volume fractions of insulating particles.

To estimate the role of the interface, Hasselman and Johnson (1987) proposed a model for composite conductivity, $K_{\mathrm{c}}$. This includes the interfacial heat transfer coefficient or thermal conductance, $h\left(\mathrm{~W} \mathrm{~m}^{-2} \mathrm{~K}^{-1}\right)$.

$$
K_{\mathrm{C}}=K_{\mathrm{M}} \frac{2 f\left(K_{\mathrm{I}} / K_{\mathrm{M}}-K_{\mathrm{I}} / r h-1\right)+K_{\mathrm{I}} / K_{\mathrm{M}}+2\left(K_{\mathrm{I}} / r h\right)+2}{f\left(1-K_{\mathrm{I}} / K_{\mathrm{M}}+K_{\mathrm{I}} / r h\right)+K_{\mathrm{I}} / K_{\mathrm{M}}+2\left(K_{\mathrm{I}} / r h\right)+2},
$$

where $f$ is the volume fraction of inclusions; $C, M$ and $I$ refer to composite, matrix and inclusion respectively; and $r$ is the radius of the inclusions assumed to be spherical. This equation is valid only for 'dilute' composites, in which disturbance to the thermal field around an inclusion does not overlap with the disturbance from surrounding inclusions.

The effect of reinforcement/matrix interface on the damping behaviour of the composites has been investigated by Zhang et al (1993). Schoek theory which was proposed to explain the phenomenon of internal friction in alloys has been used to explain the same for MMCs. According to the theory, internal friction is increased by the relaxation at semicoherent or incoherent precipitate/matrix interfaces and the anelastic strain contributed by dislocations close to the interface. Resultant composite 
internal friction was found to be proportional to the volume fraction of reinforcement in the composite. In the MMCs, not only is the interface area large, but also CTE mismatch between particulates and matrix result in stress concentration at the incoherent interfaces, which increases the internal friction. At higher temperatures, when the matrix softens relative to the hard reinforcement, a reversible movement of vibrations is expected to occur at the interface and this can be used to explain increase in interface damping with temperature. In $2519 \mathrm{Al} \mathrm{MMCs}$, the largest role of interface could be seen at temperatures between $250^{\circ} \mathrm{C}$ and $350^{\circ} \mathrm{C}$.

\section{Effect on yield strength and elongation}

We have earlier discussed the effect of brittle reaction products at the interface on the load transfer efficiency of the interface which is adversely affected. Similarly, coarse intermetallic precipitates at the $\mathrm{Al}-\mathrm{Cu}-\mathrm{Mg}$ alloy/SiC interfaces are detrimental to all mechanical properties. The feedback from the above reports is that a clean interface is always desirable.

Even if there are no reaction products at the interface and the matrix, particle sizes and shapes are the same, the yield strength, modulus and tensile ductility vary based on the nature of chemical bond. This is evident from the data shown in table 7 for mechanical properties of pure $\mathrm{Al}$ and $\mathrm{Al} / \mathrm{SiC}, \mathrm{Al} / \mathrm{B}_{4} \mathrm{C}, \mathrm{Al} / \mathrm{TiC}$ and $\mathrm{Al} / \mathrm{TiB}_{2}$ composites prepared by $\mathrm{P} / \mathrm{M}$ process at DMRL.

It is obvious that the highest increase in yield and ultimate tensile strength is observed for $\mathrm{Al} / \mathrm{TiC}$. Improvement in strength is through load transfer at the interface as well as dislocation-particle and dislocation-dislocation interactions. Of course, the excellent bond integrity of $\mathrm{Al} / \mathrm{TiC}$ interface explains why $\mathrm{Al} / \mathrm{TiC}$ composite has the highest increase in yield and ultimate tensile strength.

The resistance of the interface to cracking even at high strains in the surrounding matrix is also essential for a significant role in load transfer. A brittle interface will crack at lower strains leading to little load transfer. In table 7, Al/TiC composite also shows maximum strain to fracture. Remarkable elongation of $20 \%$ or more has been seen in $15 \mathrm{vol} \% \mathrm{XD} \mathrm{Al} / \mathrm{TiC}$ at room temperature, partly as the particles were equiaxed and also because interfacial bonding was excellent (Mitra 1993). Even after cold rolling to $75 \%$ reduction, cracks could be seen at only a few interfaces, where particles formed clusters. This is unlike the situation seen in many other interfaces like $\mathrm{Al} / \mathrm{Al}_{2} \mathrm{O}_{3}$ (Ruedl 1969) and $\mathrm{Cu} / \mathrm{SiO}_{2}$ and $\mathrm{Cu} / \mathrm{Al}_{2} \mathrm{O}_{3}$ (Humphreys and Stewart 1972). The regions around the interface are highly misoriented with respect to surrounding

Table 7. Tensile properties of some $\mathrm{P} / \mathrm{M}$ as-extruded aluminium matrix composites (Kuruvilla et al 1989).

\begin{tabular}{lccc}
\hline Composite & YS(MPa) & UTS(MPa) & Elongation (\%) \\
\hline Pure Al(P/M) & 64 & 90 & 21 \\
$\mathrm{Al} / 20 \mathrm{v} / \mathrm{o} \mathrm{SiC}$ & 117 & 200 & $11 \cdot 4$ \\
$\mathrm{Al} / 20 \mathrm{v} / \mathrm{o} \mathrm{TiC}$ & 148 & 233 & 15.6 \\
$\mathrm{Al} / 20 \mathrm{v} / \mathrm{o} \mathrm{B}_{4} \mathrm{C}$ & 143 & 208 & 9.0 \\
$\mathrm{Al} / 20 \mathrm{v} / \mathrm{o} \mathrm{TiB}_{2}$ & 121 & 166 & 14.8 \\
\hline
\end{tabular}




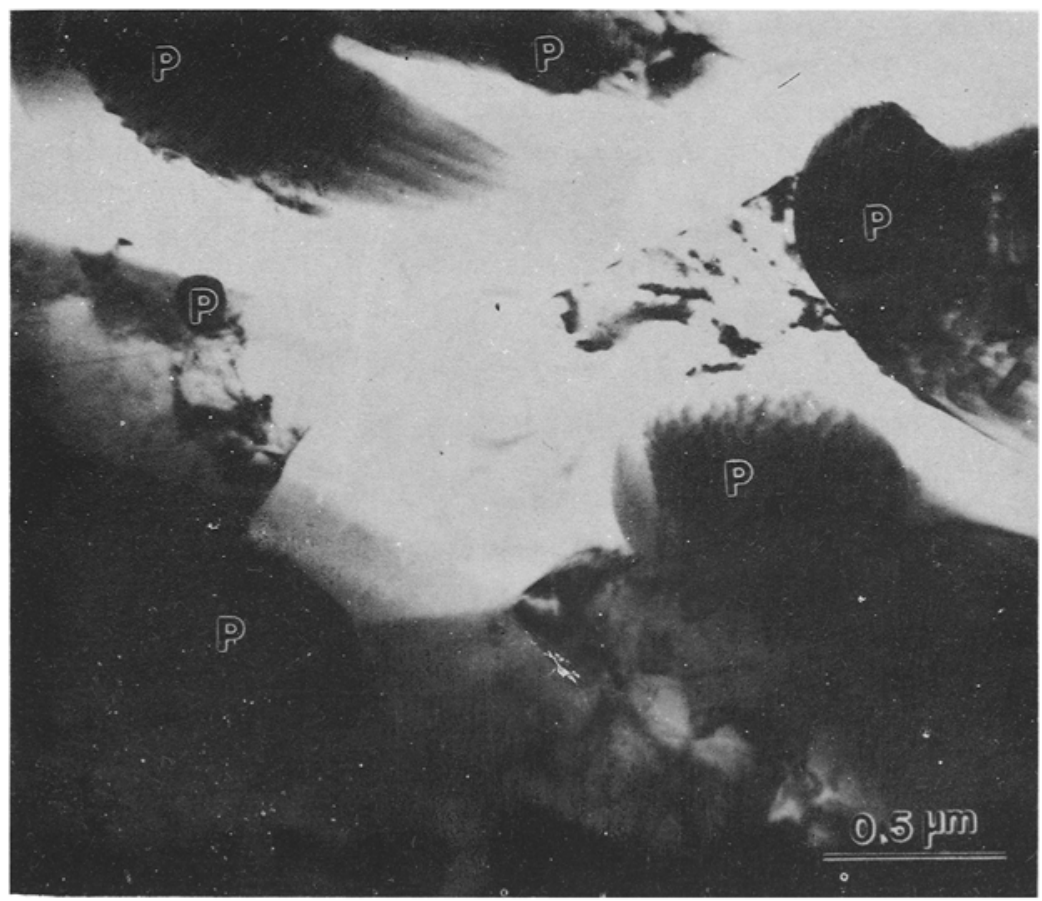

Figure 15. TEM micrograph of microstructure of XD Al/TiC composite after room-temperature tension test larea close to fracture surface). Regions around the particles are misoriented $w$ th respect to each other and hence the contrasts are different (Fine et al 1993).

regions resulting in local lattice rotation as shown in figure 15 (Fine et al 1993; Mitra 1993). The mechanism of local lattice rotation in dispersion-hardened alloys has been discussed by Ashby (1966) and Humphreys (1979). The high ductility of the Al/TiC interface can only be explained based on the metallic nature of bonding. In another investigation (Earvolino et al 1992). Al containing $15 \mathrm{vol} \%$ tetragonal D0 $0_{23}$ structured $\mathrm{Al}_{3} \mathrm{Zr}_{0.25} \mathrm{Ti}_{0.75}$, prepared by casting, was cold-rolled to $0.017 \%$ of the original thickness with a few intermediate anneals. While the intermetallic was fractured, the Al flow kept the interface intact and no cracks could be seen at Al-intermetallic interfaces. The $\mathrm{Al} \mathrm{Al}_{2} \mathrm{O}_{3}, \mathrm{Cu} \mathrm{SiO}_{2}$ and $\mathrm{Cu}_{1} \mathrm{Al}_{2} \mathrm{O}_{3}$ interfaces, which are less ductile, will crack at smaller strains and not much local lattice rotation cań take place as has been explained by Humphreys.

\section{Effect on creep resistance}

The creep threshold stress $\sigma_{0}$ is the index of resistance to creep and for particlereinforced composites this is given by

$$
\sigma_{0}=K \cdot\left(E_{\mathrm{c}} / E_{\mathrm{m}}\right)^{m}
$$

$\sigma_{0}$ is independent of particle size and temperature, and increases with increase in the volume fraction of the reinforcement. The origin of $\sigma_{0}$ is related to the load transfer at 
the matrix-reinforcement interface, which of course depends on the interface bond integrity. This can be seen from table 8 . The $\mathrm{XD} \mathrm{Al} / \mathrm{TiB}_{2}$ composite has shown higher threshold stress compared to that prepared by conventional $\mathrm{P} / \mathrm{M}$ process, which is due to stronger interface as well as finer particle size in the former. $\mathrm{Al} / \mathrm{SiC}$ shows the highest creep threshold stress, as the matrix-reinforcement bonding is stronger than that in $\mathrm{Al} / \mathrm{TiB}_{2}$, which is indicated by comparison of $E(\operatorname{expt}) / E(\mathrm{ROM})$ ratio (figure 3$)$.

\section{Interface engineering}

It is well understood how important interfaces are in determining the performance of MMCs. We have seen how processing methods, ageing and heat treatments can affect the interfacial bond and properties. Hence there is a drive for developing the technology to tailor interfaces to achieve desired properties. Of course, processing methods and heat treatments can be devised and alloying elements can be added in order to modify interfaces. The other option is to treat the surfaces of the reinforcements, which play a crucial role in wetting. Some of the strategies to improve interfacial properties are outlined in table 9.

Table 8. Table reporting $E(\operatorname{expt}) / E(\mathrm{ROM})$ and $\sigma_{0}$ values (Pandey 1993) for composites with different reinforcement and processing methods.

\begin{tabular}{lcc}
\hline Material & $E(\operatorname{expt}) / E(\mathrm{ROM})$ & $\sigma_{\mathrm{o}}(\mathrm{MPa})$ \\
\hline $\mathrm{PM} \mathrm{Al} / 20 \mathrm{v} / \mathrm{o} \mathrm{SiC}_{\mathrm{p}}$ & 0.73 & $25 \cdot 2$ \\
$\mathrm{PM} \mathrm{Al} / 20 \mathrm{v} / \mathrm{o} \mathrm{TiB}_{2}$ & 0.60 & $14 \cdot 3$ \\
$\mathrm{XDAl} / 20 \mathrm{v} / \mathrm{O} \mathrm{TiB}_{2}$ & 0.82 & $19 \cdot 2$ \\
\hline
\end{tabular}

Table 9. Strategies to exploit full potential of metal matrix composites by tailoring interfaces.

\begin{tabular}{|c|c|}
\hline Strategy & Example \\
\hline 1. Use of in situ processes & $X D$, reactive casting \\
\hline $\begin{array}{l}\text { 2. Use of nonstoichiometric compounds as } \\
\text { reinforcements }\end{array}$ & $\mathrm{TiC}_{1-x}$ instead of $\mathrm{TiC}$ \\
\hline $\begin{array}{l}\text { 3. Development and use of novel reinforcements } \\
\text { with metallic bonding }\end{array}$ & $\mathrm{Ti}_{5} \mathrm{Si}_{3}, \mathrm{TiSi}_{2}, \mathrm{Cr}_{3} \mathrm{C}_{2}$, etc. \\
\hline $\begin{array}{l}\text { 4. Novel techniques to modify reinforcement } \\
\text { surfaces for improved bonding }\end{array}$ & $\begin{array}{l}\text { Decarburization of } \mathrm{TiC} \\
\text { Ion implantation, Irradiation }\end{array}$ \\
\hline 5. Matrix alloying for enhanced bonding & $\begin{array}{l}\text { Addition of } \mathrm{Ti}, \mathrm{Cr}, \mathrm{La}, \mathrm{Ce}, \mathrm{Li} \text { in } \mathrm{Al} / \mathrm{SiC} \\
\text { system; } \mathrm{Mg} \text { and } \mathrm{Li} \text { to } \mathrm{Al} / \mathrm{Al}_{2} \mathrm{O}_{3} \text { system }\end{array}$ \\
\hline $\begin{array}{l}\text { 6. Development of innovative coating techniques } \\
\text { for reinforcements }\end{array}$ & $\begin{array}{l}\text { Sputtered coatings, duplex coatings, } \\
\text { graded coatings, sol-gel coatings, } \\
\text { in situ modification of coatings }\end{array}$ \\
\hline 7. Thermomechanical treatment & $\begin{array}{l}\text { Deformation and recrystallization in } \\
\mathrm{XD} \mathrm{Al} / \mathrm{TiC} \text { composites led to higher } \\
\text { degree of semicoherency at interfaces }\end{array}$ \\
\hline
\end{tabular}


Mcdonald and Ransley (1954) pretreated TiC particles by heating in moist hydrogen at $1000^{\circ} \mathrm{C}$ leading to removal of the oxide layer on the surface and partial decarburization of surfaces. This leaves a metallic Ti layer on the surface. It has already been discussed in an earlier section that $\mathrm{TiC}\{111\}$ surfaces ending with $\mathrm{Ti}$ have the same surface electronic structure as $\mathrm{Ti}\{0001\}$ and $\mathrm{Ti}$ sites on $\{100\}$ surfaces are more active when these are carbon-deficient. Removal of oxide layer also probably resulted in establishment of direct contact and an equilibrium between the atoms of matrix and reinforcing phase and hence a strong chemical bond. Thus pretreatment with hydrogen resulted in significant increase in Young's modulus. This also proves once again our earlier proposition that metallic bonds result in a more efficient load transfer.

Another and quite popular surface modification method is coating with a third phase to improve wetting or prevent adverse chemical reaction. Coating material is normally wetted well by the $\mathrm{Al}$ matrix, such as $\mathrm{Ni}$ on $\mathrm{TiC}$. $\mathrm{TiB}_{2}$ coating applied by CVD, which is also an excellent wetting agent works on a different principle (Maruyama et al 1991). Bulk $\mathrm{TiB}_{2}$ is not wetted as well by $\mathrm{Al}$ as $\mathrm{CVD} \mathrm{TiB}_{2}$ coating on $\mathrm{SiC}$ and $\mathrm{C}$ fibres is. It has been reported by $\mathrm{Wu}(1988)$ that $\mathrm{CVD}$-deposited $\mathrm{TiB}_{2}$ contains significant amounts of chlorine and wetting in $\mathrm{C} / \mathrm{Al}$ system is related to the concentration of chlorine. Thus it was hypothesized that enhanced wetting action was due to the fluxing action of chlorine, which destabilized the surface aluminium oxide and allowed direct contact betwe` $n$ liquid $\mathrm{Al}$ and the reinforcement.

Recently, Johnson and Sonup urlak (1993) investigated the effect of coating diamond particles (modulus $=1050 \mathrm{GPa}$ ) with $\mathrm{SiC}$ using chemical vapour infiltration. $\mathrm{SiC}$ not only helps in improving wettability, but retards formation of $\mathrm{Al}_{4} \mathrm{C}_{3}$, which is detrimental because of its tendency to corrode in moist environments. Also, $\mathrm{Al}_{4} \mathrm{C}_{3}$ has poor thermal conductivity and it defeats the purpose of reinforcing with diamond for preparing composites having high thermal conductivity. The increase in $\mathrm{SiC}$ coating thickness of diamond reinforcements monotonously increases the thermal conductivity of the composites. It is visible that Young's modulus increases with increase in coating thickness; there is also an overall decrease in the coefficient of thermal expansion. These are due to changes in the interface bond due to coating as well as increase in volume fraction of $\mathrm{SiC}$.

\section{Conclusions}

In this paper, we have analysed some of the existing information about interfaces in the composites of interest to understand their nature and relationship with mechanical properties. The variables controlling the characteristics of interfaces are quite large in number, such as processing (technique, temperature, etc.) as well as composition and chemical nature of matrix and reinforcement. Processing variables can be manipulated to enhance the wetting between matrix and reinforcement, like addition of alloying elements, pretreatment or coating of reinforcements, increase of temperature of molten metal, hot pressing the blended metal and ceramic powders above solidus temperature, etc. Ageing of the matrix with high solid solubility also affects the interface structure and chemistry.

The chemical bond at the interface can be through a chemical reaction or electronic. The former is detrimental as it leads to a brittle reaction product at the interface, whereas 
the latter is desirable. For electronic bonding, intimate contact between the atoms of the matrix and of the ceramic phase is necessary and this is found more easily in the in situ composites. That is the reason some matrix-particle interfaces in XD composites are semicoherent and improvement in Young's modulus values are higher than those seen in composites prepared by conventional processes. Factors responsible for enhancement of interfacial bonding in metal/ceramic systems are: (i) presence of densely packed planes parallel to interface in either or both the reinforcement and the matrix phases, (ii) presence of charged defects close to interface, (c) substoichiometric composition of the reinforcement, and (d) lower heat of formation of the reinforcements.

Of a variety of reinforcements, the ones having metallic character form metallic bonds with the metal matrix. In such cases, the matrix-reinforcement interfacial bonding is stronger than in other metal-ceramic composites and this leads to a greater improvement in Young's modulus, yield and ultimate tensile strength values over those of the matrix material. Tensile ductility is also impressive in case of metallic bonding at interfaces as they can withstand higher strains. Although the incorporation of the reinforcements which give rise to metallic bonding at the interfaces results in superior properties compared to others, most of the potential ceramic reinforcements possess ionic or covalent bonding. Hence modification of interfaces is necessary to enhance the metallic character of the bond. Because of the critical role played by interfaces in the composites, it is necessary to plan the choice of matrix and reinforcement and processing conditions while keeping an eye on the nature of the interfaces expected.

\section{Acknowledgements}

The authors gratefully acknowledge several useful discussions and research results from M/s V V Bhanuprasad, B V R Bhat, M K Jain, A B Pandey, V K Varma, Dr S V Kamat, K S Prasad and Dr A K Kuruvilla. One of the authors (RM) is thankful to Professor Morris E Fine and Professor Julia R Weertman for their guidance in successful completion of his $\mathrm{PhD}$ research at the Northwestern University, USA. Thanks are also due to Sri S L N Acharyulu, Director, Defence Metallurgical Research Laboratory, for his encouragement.

\section{References}

Aikin Jr R M 1989 NASA Contractor Report 4365, Contract NAS 1-18531

Arsenault R J 1984 Scr. Metall. 181131

Arsenault R J 1994 Composites 27540

Ashby M F 1966 Philos. Mag. 141157

Bhanuprasad V V, Prasad K S, Kuruvilla A K, Pandey A B, Bhat B V R and Mahajan Y R 1991 J. Mater. Sci. 26460

Bonollo F, Guerriero R, Sentimenti E, Tangerini I and Jang L M 1991 Advanced structural inorganic composites (ed.) P Vincenzini (Amsterdam: Elsevier Science Publishers) p. 259

Bradshaw A M, Van der Veen J F, Himpsel F J and Eastman D E 1980 Solid State Commun. 3737

Brown N R 1993 Effect of heat treatment on interfaces in magnesium metal matrix composites, Ph D Dissertation, Northwestern University, Illinois, USA

Calderon H A, Fine M E and Weertman J R 1988 Metall. Trans. A19 1135

Carim A H 1991 Mater. Lett. 12153

Chawla K K 1987 Composite materials: Science and engineering (New York: Springer Verlag) p. 83 
Chiou J -M and Chung D D L 1990 Metal and ceramic matrix composites: Processing, modelling and mechanical behaviour (eds) R B Bhagat, A H Clauer, P Kumar and A M Ritter (Warrendale, P A: TMS) p. 107

Cisse J, Bolling G F and Keer H W 1972 J. Cryst. Growth 13/14 771

Clough R B, Biancaniello F S, Wadley H N G and Kattner U R 1990 Metall. Trans. A21 2747

Date S K 1994 Private communication, NCL, Pune

Delannay F, Froyen L and Deruyttrere A 1987 J. Mater. Sci. 221

Dhingra A K 1980 Philos. Trans. R. Soc. A294 151

Earvolino P A, Fine M E, Weertman J R and Parameswaran V R 1992 Scr. Metall. Mater. 26945

Easterling K E, Fischmeister H F and Navara E 1973 Powder Metall. 16128

Eid N M A and Thomason R F 1979 Acta Metall. 271239

Feng C R, Michael D J and Crowe C R 1991 Mater. Sci. Eng. A145 257

Fine M E 1981 Scr. Metall. 15523

Fine M E, Bourell D L, Eliezer Z, Persad C and Marcus H L 1988 Scr. Metall. 22907

Fine M E, Mitra R and Weertman J R 1993 Z. Metallkd. 4282

Finnis M W, Stoneham A M and Tasker P W 1990 Metal-ceramic interfaces: Acta Scripta Metallurgica Proceedings Series (eds) M Ruhle, A G Evans, M F Ashby and J P Hirth (New York: Pergamon Press) Vol. 4 , p. 35

Fuchs G E 1990 Metal and ceramic matrix composites: Processing, modelling and mechanical behaviour (eds) R B Bhagat, A H Clauer, P Kumar and A M Ritter (Warrendale, PA: TMS) p. 391

Fuchs G E, Abonneau E, Treilleux M and Perez A 1989 Mater. Sci. Eng. A109 83

Gao Y and Merkle K L 1992 Siructure and properties of interfaces in materials: MRS Symp. Proc. (eds) W A T Clark, U Dahmen and C L Briant (Pittsburgh, PA: MRS) Vol. 238, p. 775

Geiger A L, Hasselman D P H and Donaldson K Y 1993 J. Mater. Sci. Lett. 12420

Geiger A L and Jackson M 1989 Adv. Mater. Proc. 723

Goretzki H 1967 Phys. Status Solidi 20 K141

Goretzki H, Exner H E and Scheuermann W 1971 Modern developments in powder metallurgy (ed) H H Hausner 4327

Hashin Z and Shtrikman S 1963 J. Mech. Phys. Solids 11127

Hasselman D P H and Johnson L F 1987 J. Compos. Mater. 21508

Hasselman D P H and Donaldson K Y 1992 J. Am. Ceram. Soc. 753137

Hawk J A, Mirchandani P K, Benn R C and Wilsdorf H G F 1988 Dispersion strengthened aluminium alloys (eds) Y -W Kim and W M Griffith (Warrendale, PA: TMS) p. 551

Henager Jr C H, Brimhall J L and Hirth J P 1992 Ceram. Sci. Eng. Proc. 13596

Henriksen B R and Gionnes J 1991 Advanced structural inorganic composites (ed.) P Vincenzini (Amsterdam: Elsevier Sci. Pub.) p. 251

Homeny J, Neergard L J, Harasek K. R, Donner J T and Bradley S A 1990 J. Am. Ceram. Soc. 73102

Howe I M 1993 Inter. Mater. Rev. 38233

Humphreys F J 1979 Acta Metall. 271801

Humphreys F J and Stewart A T 1972 Surf. Sci. 31389

Iseki T, Kameda T and Maruyama T 1984 J. Mater. Sci. 191692

Jain M K, Bhanuprasad V V, Kamat S V, Pandey A B, Varma V K, Bhat B V R and Mahajan Y R 1993 Int. J. Powder Metall. 29267

Johnson W B and Sonuparlak B 1993 J. Mater. Res. 81169

Jones C, Kiely C J and Wang S S 1989 J. Mater. Res. 4327

Kimura Y, Mishima Y, Umekawa S and Suzuki I 1984 J. Mater. Sci. 193107

Koczak M J and Kumar K S 1989 U S Patent 4, 808, 372

Konitzer D G and Loretto M H 1989a Acta Metall. 37397

Konitzer D G and Loretto M H 1989b Mater. Sci. Technol. 5627

Kuruvilla A K, Bhanuprasad V V, Prasad K S and Mahajan Y R 1989 Bull. Mater. Sci. 12495

Kuruvilla A K, Prasad K S, Bhanuprasad V V and Mahajan Y R 1990 Scr. Metall. 24873

Krock R H 1966 Modern developments in powder metallurgy (ed.) H H Hausner (New York: Plenum Press) p. 105

Lagace H and Lloyds D J 1989 Canadian Met. Quart. 28145

Lee D J, Vaudin M D, Handwerker C A and Kattner U A 1988 Mater. Res. Soc. Symp. Proc. 120357

Levi C G, Abbaschian G J and Mehrabian R 1978 Metall. Trans. A9 697

Lim C B, Yano T and Iseki T $1989 J$. Mater. Sci. 244144 
Lloyd D J and Jin I 1988 Metall. Trans. A19 3107

Lucas J P, Yang N Y C and Stephens J J 1992 Structure and properties of interfaces in materials; Mater. Res. Soc. Symp. (eds) W A T Clark, U Dahmen and C L Briant (Pittsburgh, PA: MRS) Vol. 238, p. 877

Lyle J P Jr 1967 Aluminum (ed.) K R Van Horn (Metals Park, OH: ASM) Vol. 1, Ch. 10, p. 337

Mader W 1992 Structure and properties of interfaces in solids; MRS Symp. Proc. (eds) W A T Clark, U Dahmen and C L Briant (Pittsburgh, PA: MRS) p. 763

Mahajan Y R and Rama Rao P 1992 New materials (eds) S K Joshi, C N R Rao, T Tsuruta and S Nagakura (New Delhi: Narosa Pub. House) p. 322

Manning C R and Gurganus T B 1969 J. Am. Ceram. Soc. 52115

Manoharan M and Lewandowski J J 1989 Scr. Metall. 23301

Marcus H L and Rabenberg L K 1987 ONR Contract N00014-84-K-0687, Technical Report UTCMSE-873 , p. 160

Maruyama B, Barrera E V and Rabenberg L 1991 Metal matrix composites: Processing and interfaces (eds) R K Everett and R J Arsenault (San Diego, CA: Academic Press) p. 181

Mcdonald N F and Ransley C E 1954 Metal powder review: Symp. on powder metallurgy, p. 242

Meschter P J and Schwartz D S 1989 JOM 4152

Mitra R 1993 Microstructure and interfaces in XD Al/TC metal matrix composites, Ph D Dissertation, Northwestern University, Illinois, USA

Mitra R, Chiou W-A, Weertman J R, Fine M E and Aikin Jr R M 1992a Structure and properties of interfaces in materials; MRS Symp. Proc. (eds) W A T Clark, U Dahmen and C L Briant (Pittsburgh, PA: MRS) Vol. 238, p. 871

Mitra R, Weertman J R, Fine M E and Aikin Jr R M 1992b Developments in ceramic and metal matrix composites (ed.) K Upadhya (Warrendale, PA: TMS) p. 125

Mitra R, Fine M E and Weertman J R 1993a J. Mater. Res. 82370

Mitra R, Chiou W A, Fine M E and Weertman J R 1993b J. Mater. Res. 82380

Mitra R, Mahajan Y R, Prasad N E, Chiou W A and Ganguly C 1995 Key engineering materials: Metal and ceramic matrix composites (ed.) F H Wohlbier (Switzerland: Trans Tech Publications)

Nicholas M G 1987 Fundamentals of diffusion bonding (ed.) Y Ishida (New York: Elsevier) p. 25

Ning X G, Pan J, Hu K Y and Ye H Q 1992 Structure and properties of interfaces in solids (eds) W A T Clark, U Dahmen and C L Briant (Pittsburgh, P A: MRS) Vol. 238, p. 865

Nogi K, Tsujimoto M K, Ogino K and Iwamoto N 1992 Acta Metall. Mater. 401045

Norman J H, Reynolds G H and Brewer L 1990 Mater. Res. Soc. Symp. Proc. (Pittsburgh, PA: MRS) p. 369

Nutt S R 1986 Interfaces in metal matrix composites (eds) A K Dhingra and S G Fishman (Warrendale, PA: TMS) p. 157

Nutt S R and Carpenter R W 1985 Mater. Sci. Eng. 75169

Oh S Y, Cornie J A and Russel K C 1989 Metall. Trans. A20 533

Ohuchi F S 1987 Interface science and engineering: J. Phys. (eds) R Raj and S L Sass (New York) Vol. C5, p. 783

Pandey A B 1993 Creep behaviour of particulate reinforced aluminium matrix composites, Ph D Dissertation, Banaras Hindu University, Varanasi

Quigley B F, Abbaschian G J, Wunderlin R and Mehrabian R 1982 Metall. Trans. A13 93

Rack H J 1988 Dispersion strengthened aluminium alloys (eds) Y -W Kim and W M Griffith (Warrendale, PA: TMS) p. 649

Radmilovic V, Thomas G and Das S K 1991 Mater. Sci. Eng. A132 171

Ramqvist J V 1965 Int. J. Powder Metall. 12

Ratnaparkhi P L and Howe J M 1992 Scr. Metall. Mater. 27133

Reeves A J, Stobbs W M and Clyne T W 1987 Metal matrix composites-Processing, microstructure and properties (eds) N Hansen, D Juul Jensen, T Leffers, H Liholt, T Lorentzen, A S Pederson, O B Pederson and B Ralph (Rosklide, Denmark: Riso National Laboratory Press) p. 631

Reeves A J, Taylor R and Clyne T W 1991 Mater. Sci. Eng. A141 129

Reuss A 1929 Z. Angew. Math. Mech. 955

Rhee S K 1970 J. Am. Ceram. Soc. 53386

Ribes H, Da Silva R, Suery M and Bretheau T 1990 Mater. Sci. Tech. 6621

Ruedl E 1969 J. Mater. Sci. 4814

Satyaprasad K, Mahajan Y R and Bhanuprasad V V 1992 Scr. Metall. Mater. 26711

Satyaprasad K and Mahajan Y R 1994 Scr. Metall. Mater. 301049 
Skinner D J 1988 Dispersion strengthened aluminum alloys (eds) Y -W Kim and W M Griffith (Warrendale, PA: TMS) p. 181

Sritharan T, Xia K, Heathcock J and Mihelich J 1990 Metal and ceramic matrix composites: Processing, modelling and mechanical behaviour (eds) R B Bhagat, A H Clauer, P Kumar and A M Ritter (Warrendale, PA: TMS) p. 13

Samsonov G V, Panasyuk A D and Kozina G K 1968 Sov. Powder Metall. Met. Ceram. 71874

Schroder V, Kainer K U and Mordike B L 1989 Developments in the science and technology of composite materials: Proc. of the third European conf. on composite materials, Bordeaux, France (eds) A R Bunsell, P Lamicq and A Massiah (Amsterdam: Elsevier Applied Science) p. 221

Schroder J, Kainer K U and Mordike B L 1991 Proc. P/M 91: Int. conf. on P/M aerospace materials, Lausanne, Switzerland

Skinner D J, Zedalias M S, Frazier W E, Kockzak M J and Sahoo P 1990 Metal and ceramic matrix composites: Processing, modelling and mechanical behaviour (eds) R B Bhagat, A H Clauer, P Kumar and A M Ritter (Warrendale, PA: TMS) p. 535

Stoneham A M and Tasker P W 1985 J. Phys. C18 L543

Sunwoo H, Fine M E, Meshi M and Stone D H 1982 Metall. Trans. A13 2035

Suzuki M, Nutt S R and Aikin R M Jr 1993 Mater. Sci. Eng. A162 73

Tombrello T A 1984 Mater. Res. Soc. Symp. Proc. 25

Van Den Burg M and De Hosson J Th M 1992 Acta Metall. Mater. 40 S281

Voight W 1928 Lehrbuch der Kristallphysik (Leipzig: Teubner) p. 716

Wang L and Arsenault R J 1991 Metall. Trans. A22 3013

Warner T J and Stobbs W M 1989 ICCM: Proc. 7th Int. conf. on comp. mater. (eds) Wu Yunshu, Gu Zhenlong and Wu Renjie (New York: International Academic Press and Pergamon Press) Vol. 1, p. 503

Warwick M and Clyne R T W 1989 Developments in the science and technology of composite materials: Third European conf. on composite materials (eds) A R Bunsell, P Lamicq and A Massiah (France: Elsevier Applied Science) p. 205

Webster D 1982 Metall. Trans. A13 1511

Weimin S, Pengxing L and Geyang L 1991 Composites: Design, manufacturing and application, Proc. ICCM/VIII (eds) S Tsai and G S Springer (Covina, CA: SAMPE) $19 \mathrm{k} 3$

Westwood A R C 1988 Metall. Trans. A19 749

Westwood A R C and Winzer S R 1987 Advancing materials research (eds) P A Paras and H D Langford (Washington, D.C.: Nat. Acad. Press) p. 225

White J, Willis T C, Hughes I R and Jordan R M 1983 Dispersion strengthened aluminium alloys (eds) Y -W Kim and W M Griffith (Warrendale, PA: TMS) p. 693

Wu R 1988 Interfaces in polymer, ceramic and metal matrix composites (ed.) H Ishida (New York: Elsevier) p. 43

Wu Y and Lavernia E J 1991 JOM 4316

Xia K, Nieh T G, Wadsworth J and Langdon T G 1990 Fundamental relationships between microstructure and mechanical properties of metal-matrix composites (eds) P K Liaw and M N Gungor (Warrendale, PA: TMS) p. 543

Xu Z R, Chawla K K, Mitra R and Fine M E 1994 Scr. Metall. Mater. 311525

Yokokawa H, Sakai N, Kawada T and Dokiya M 1991 Metall. Trans. A22 3075

Young T 1805 Trans. R. Soc. 9465

Zedalias M S, Ghate M V and Fine M E 1985 Scr. Metall. 19647

Zhang J, Perez R J, Gupta M and Lavernia E J 1993 Scr. Metall. 2891 